Noname manuscript No.

(will be inserted by the editor)

\title{
The impact of electoral rules on manufacturing industries: Evidence of disaggregated data of 61 industries of 55 countries
}

\author{
Timothy Yu-Cheong Yeung · Izaskun Zuazu
}

the date of receipt and acceptance should be inserted later

\begin{abstract}
Electoral rules are found to induce different incentives to politicians and have an effect on the economic performance of countries. The literature is however silent on whether this effect is homogeneous across industries within a country. This paper argues with an analytical model that an incumbent government under majoritarian rules tends favour larger industries so as to secure votes from the employees and relatives of those industries. By constructing and exploiting an original dataset that covers disaggregated data on output growth of 61 industries in 55 countries, we find that larger industries in terms of employment size grow slower than smaller ones under nonmajoritarian electoral rules, but such a correlation is absent under majoritarian rule. This result is robust across different regression models and could well be explained by favouritism of governments towards larger industries.
\end{abstract}

Keywords Electoral rules $\cdot$ manufacturing industry growth $\cdot$ industry size $\cdot$ disproportionality $\cdot$ special interest groups

JEL Classification: D72, H11, L60

Timothy Yu-Cheong Yeung

KU Leuven

E-mail: yucheong.yeung@kuleuven.be

Izaskun Zuazu

University of Duisburg-Essen

E-mail: izaskun.zuazu-bermejo@uni-due.de 


\section{Introduction}

This paper investigates whether electoral rules determine the economic performance of manufacturing industries, and whether this effect is heterogeneous across industries within an economy. Electoral rules convert votes into political representatives in different manners and, therefore, provide different incentives to incumbent governments to react to different groups of voters. Electoral rules in legislative elections characterize two broad electoral systems: majoritarian electoral systems (MR, hereafter) and proportional representation systems (PR, hereafter). The adoption of alternative electoral systems (Boix, 1999, Benoit, 2004, Colomer, 2016, Yeung, 2017) and their political consequences (Lijphart, 1990, Norris, 2004) have long been studied in political science. Along similar lines, the economic implications of electoral rules have also attracted scholarly attention (Rodrik, 1996, Persson et al. 2003; Knutsen, 2011). Yet there is no robust consensus on which type of electoral rule is more conducive to economic growth 1 -

The mechanism linking the electoral rule a country adopted to the overall macroeconomic growth is complex, intertwined with many other factors. Theories and evidence at the macroeconomic level are thus nonetheless weak. Our work instead provides a theoretical link between electoral rules and incentive to favour certain industries and empirical evidence using an original industry-level dataset. The electoral rules in place are found to affect the type and size of public spending. Under proportional elections politicians, scholars find that politicians seek support from larger groups within the electorate by funding broad spending programs, such as welfare programs (Persson et al., 2003; De Haan and Klomp, 2013). To the contrary, politicians under majoritarian elections have strong incentives to target policies toward particular constituencies (De Haan and Klomp, 2013).

Industrial policies are often thought to be a politically efficient way to target key voters (Chang, 2008). Similarly, electoral rules also unleash heterogeneous effects across economic sectors within an economy. Alternative electoral rules provide different incentives to cater to different sectors and industries and thus, lead to different policy outcomes that might favour certain sectors to the detriment of other sectors (Rickard, 2012a). Political scientists and pundits alike identify many instruments by which governments can privilege industries, such as subsidies, tax exemptions, low-interest loans, debt reduction, tariffs, and quotas, and how they may differ under alternative electoral rules 2

Camyar and Ulupinar (2019) suggests that existing research on the economic impact of electoral systems exclusively focuses on economic policy without considering economic outcomes and, thus, it falls short of establishing the economic relevance of electoral systems in practical terms. Camyar and Ulupinar (2019) argues that the current literature emphasizes on macroeconomic outcomes without paying attention to the potential microeconomic outcomes and heterogeneous effects of constitutions. Looking at the aggregate economic effect of electoral rules might hide dynamics and within-country patterns that can solely be uncovered using disaggregated data. Focusing on macroeconomic outcome variables runs the risk of the so-called ecological fallacy due to the aggregation problem, an issue that is gaining momentum in the political economy literature Aghion et al. 2007, Stockemer and Sundström, 2016, Camyar and Ulupinar, 2019, Zuazu, 2019). Our paper adds to the constitutional political economy literature by studying industrial growth rather than industrial policies. It is because, firstly, industrial policies do not necessarily imply a favourable business environment and, secondly, some industrial policies are often particular and cannot be easily summarised for a comparative study. As our dataset is relatively large compared to those in the literature, we believe that the size itself averages out any particularities interfering the positive impact of some industrial policies on industrial growth. In other words, the average economic growth differential we find can be arguably and prudently related to industrial favouritism by governments.

We provide a simple theoretical model to highlight the main tradeoff facing governments. The model highlights that an incumbent government weighs the positive "vote-buying" effect of an industrial policy and the negative

\footnotetext{
1 See Taagepera and Qvortrup 2012) for a review of the research on political and economic effects of electoral institutions.

2 An illustrative case in point for this mechanism is provided in McGillivray (2018) on the different political opportunities for the same industry (the cutlery industry) under alternative electoral rules, such as the UK and the US with majoritarian rules systems, and Germany, with a more proportional system.
} 
alienating effect on other industries, where the tradeoff is driven by the electoral rule adopted. The model abstracts from actual party competition but focuses on the incentive of the incumbent government to adopt an industrial policy to favour the largest group in the economy given the constraint that favouritism alienates other groups. In line with the literature, in particular Persson and Tabellini (1999, 2004), the model suggests that an incumbent government under a majoritarian rule tends to favour large industries as the rule rewards more seats to the incumbent party given the same industrial policy and the same magnitude of negative alienating effect.

Our work tests two main hypotheses. First, we test whether electoral rules exert a general effect on the economic performance of manufacturing industries. Second, we explore the heterogeneity of this potential effect across the industries operating in the same economy. We expect that the share of workers employed by an industry might interplay with the potential economic effect of electoral rules. The core element of this argument is that as industries get larger, they might become an attractive constituency to politicians. Politicians might target large industries by means of trade or industrial policies so as to gain the sympathy of the electorate. Similarly, politicians might be willing to block reforms to persuade certain constituencies, provided a sufficient level of electoral competition (Leonida et al. 2013). This mechanism would be more likely to work under majoritarian rules because majoritarian systems are found to be more prone to foster narrow interest politics than more proportional systems (Lizzeri and Persico, 2001; Milesi-Ferretti et al., 2002; Persson and Tabellini, 2004). We empirically test these hypotheses using United Nations Industrial Development Organization (UNIDO) industrylevel data on growth rates in a panel of 61 industries operating in 55 economies over 1990-2010. We first identify any potential growth effects on manufacturing industries of majoritarian (MR) versus non-majoritarian (non-MR) electoral rules. Second, we test whether this potential growth effect is contingent upon the level of employment. We find that larger industries under non-MR is correlated with slower growth than smaller industries, but such correlation is absent or even positive under MR.

Despite that our disaggregated approach gives insights to the impacts on industries contingent on their employment size, we are unable to identify the location or geographical distribution of industries within a country. Thus, the claims by McGillivray (2018) and Rickard (2012b) that geographic concentration is a political asset for industries under MR cannot be tested in our study. Moreover, our results might not be universally valid across all types of manufacturing activities and might restraint exclusively to the organized, formal parts of manufacturing industry ${ }^{3}$ Challenges related to endogeneity or reverse causality are alleviated with lagging our explanatory variables, though we recognize the limitations of this solution. Another problem is the scarce variability of the electoral rule indicator within countries. We employ the Fixed Effects Filtered estimator (Pesaran and Zhou, 2018) to deal with the problem. Further, we tackle this issue by employing an alternative, time-varying measure of proportionality of the parliament, namely the Gallagher index of disproportionality between votes and seats in parliaments.

The remaining of the paper is structured as follows. Section 2 reviews the literature and explains our main hypotheses. Section 3 provides a simple theoretical model. Section 4 presents the data employed before Section 5 specifies the econometric model and provides the main results of the paper. Section 6 conducts various sensitivity checks. The last section concludes.

\section{Related Literature and Hypotheses}

Electoral rules have long been the focus of research in constitutional political economy (Voigt, 2011). Theories and evidence are found between electoral rules and growth (Knutsen, 2011), public spending (Lizzeri and Persico, 2001; Persson and Tabellini, 2004), trade (Martin and Steiner, 2016) and R\&D (Krūminas, 2019).

The literature acknowledges an important tradeoff of electoral rules regarding representation and accountability (Persson and Tabellini, 2005, Carey and Hix, 2011). It is conventionally agreed that MR

\footnotetext{
3 As explained by Rodrik (2012), the UNIDO industrial statistics database is derived largely from industrial surveys, and therefore informal firms are often excluded from such surveys.
} 
parliaments, which are associated with single-party governments, are more accountable because the electorate is able to identify poorly performing politicians, and consequently vote them out of office (Benhabib and Przeworski, 2005, Powell Jr and Whitten, 1993). In the case of PR, which is normally associated with coalition governments, voters find it more difficult to pinpoint the politicians to blame on. Even if voters can differentiate politicians in terms of performance, they cannot directly vote them out due to the party-list voting system and thus "retrospective economic voting" is less feasible. PR have certain features that could countervail the potential negative effects (Knutsen, 2011). An alternative channel suggests that PR might be more likely to have positive growth effect as it tends to implement universal redistributive programs and spending programs that appeal to broader electorate than MR.

Empirical literature on any growth effect of electoral rules is still inconclusive, although some insights suggest that proportional systems might benefit economic growth (Lijphart, 2012, Persson and Tabellini, 2005, Knutsen, 2011). Our work departs from the political economic growth literature in a way that we investigate into industrial growth instead of aggregate growth and attempt to provide evidence of favouritism by incumbent governments towards industries. Milesi-Ferretti et al. (2002) and Persson and Tabellini (1999) showed how electoral rules -by determining the proportionality of votes to seats in parliaments- influence policy-making, and thus the composition of government spending. Persson et al. (2003) and Persson and Tabellini (2005) suggested that electoral systems shape the incentives of politicians on the decisions between broader or narrower spending programs: proportional electoral rules are found to produce higher public spending and lean towards general electorate and universalistic welfare programs. In contrast, majoritarian rules tend to produce lower public deficits and lower consumer prices (Carey and Hix, 2013).

Persson and Tabellini (2004) argued that since a party can win election with one quarter of the national votes (half of the votes in half of the districts) -the size of minimal coalition of voters needed to win the election under MR is smaller than under PR or mixed systems- MR governments tend to target groups and result in less inclusive polices and smaller welfare programs. Unsurprisingly, a well-establish evidence on the ground of economic consequences of electoral rules is that PR systems produce policies serving broader interests than MR. A straightforward implication of existing literature is that politicians under MR tend to favour geographically concentrated industrial interests at the expense of broader, geographically dispersed public interests (McGillivray, 2018; Rickard, 2012a).

The current paper extends the idea that employment size of industries matters in politicians' calculation. Industries that employ higher proportion of the electorate, which we measure by the share of employees to the total population, might be more liable to gain political protection and favourable policies. Consequently, we surmise that whatever the effect of MR on the economic performance of industries, it is stronger on industries that employ a higher proportion of the electorate ${ }^{4}$ Our work is also related to a small strand of literature that relies on more micro-level data. Camyar and Ulupinar (2019) found that firm performance is stronger under proportional systems, while Zuazu (2019) found evidence that the growth effect of democracy depends on the technology level.

\section{Theoretical model of alternative electoral rules}

In order to better illustrate our ideas, we build a simple analytical model that aims to highlight the most important elements of a government's decision to adopt a biased industrial policy. The model also delivers a clearly defined hypothesis for the data to test and potentially refute.

The model involves an economy consisting of two electoral districts, $A$ and $B$, of equal size. The economy has only three industries $i=1,2,3$ with employment sizes $\alpha_{i}$ and $\beta_{i}$ located in District A and B respectively. All

\footnotetext{
4 In a sense, our conjecture is reminiscent of previous works on special interest politics (Grossman and Helpman 2001), collective action literature (Esteban and Ray, 2001) and ethnic group size (Dimico, 2017). One might consider that large industries gain stronger strength to bargain and lobby by gathering a large number of employees or providing monetary campaign contribution. However, the absence of data on lobbying for our highly disaggregated approach constraints our ability to further test a potential lobbying-based explanation.
} 
voters are employed by either one of the three industries, and the employments of industries sum up to one in each district. Assume $\alpha_{1}>\alpha_{2}=\alpha_{3}$ and $\beta_{1}=\beta_{2}=\beta_{3}=1 / 3$. Therefore, industry 1 is the biggest industry, though its size may not exceed half of the total employment of District $A$ and $B$ combined.

Two parties, $X$ and $Y$, are going to compete in the next general election. Under majoritarian rule, each district has one seat. Under proportional representation, two seats are allocated by parties' vote shares. Party $X$ is the incumbent ruling party of the economy. To simplify our analysis and to focus on the incentive behind a decision to adopt an industrial policy by the incumbent government, we assume that promises by parties are not credible and thus parties are not competing over their political platforms. The incumbent has however an advantage over Party $Y$, which is to consolidate votes by adopting an industrial policy favouring one of the industries. Though not proved in the text, favouring the largest industry always dominates favouring a smaller industry. The choice is thus between having 1) no industrial policy, and 2) an industrial policy favouring Industry 1, referred as Policy (1).

Having no industrial policy means that the voters attached to each industry are indifferent between two parties, and thus the proportion of voters who vote for Party $X$ is 0.5 . Adopting Policy (1) means that all voters attached to the industry will vote for Party $X$ with probability 1 . If Party $X$ is now biased towards Industry 1 and adopts Policy (1), the proportion of other voters voting for Party $X$ is $p$, which is smaller 0.5 . The parameter $p$ is predetermined at the time of policy decision.

\subsection{Majoritarian rules systems}

Under MR and given no industrial policy, both parties have equal chance to win a seat in each district as a tie is assumed to be revolved by a fair random draw. The expected number of seats, $E\left[S_{M R}^{N o}\right]$, is thus one. Applying the usual assumption of risk aversion, a certainty of obtaining one seat dominates a scenario that involves random event despite the same expectation of seats.

If Party $X$ chooses to adopt Policy (1), the seat won in District $A$ will be:

$$
S_{A, M R}= \begin{cases}1, & \text { if } \alpha_{1}+p\left(1-\alpha_{1}\right)>\frac{1}{2} \\ 0, & \text { otherwise }\end{cases}
$$

Similarly, the seat won in District $B$ is:

$$
S_{B, M R}= \begin{cases}1, & \text { if } p>\frac{1}{4} \\ 0, & \text { otherwise }\end{cases}
$$

Given that $\alpha_{1}>1 / 3$, whenever $p>1 / 4$, the inequality that $\alpha_{1}+p\left(1-\alpha_{1}\right)>1 / 2$ must be fulfilled. In other words, a value of $p$ that rewards Party $X$ a seat in District $B$ must also reward it a seat in District $A$. The choice of whether to implement Policy (1) is thus only relevant when $p<1 / 4$.

When $p<1 / 4$, Party $X$ will lose the election in District $B$. For Policy (1) to be beneficial, it has to guarantee a seat in District $A$ by fulfilling:

$$
\begin{aligned}
\alpha_{1}+p\left(1-\alpha_{1}\right) & >\frac{1}{2} \\
p & >\frac{0.5-\alpha_{1}}{1-\alpha_{1}}
\end{aligned}
$$

By adopting Policy (1), Party $X$ obtains one seat in District $A$ with certainty, and thus Policy (1) is preferred to no industrial policy whenever inequality $(3)$ is fulfilled. 


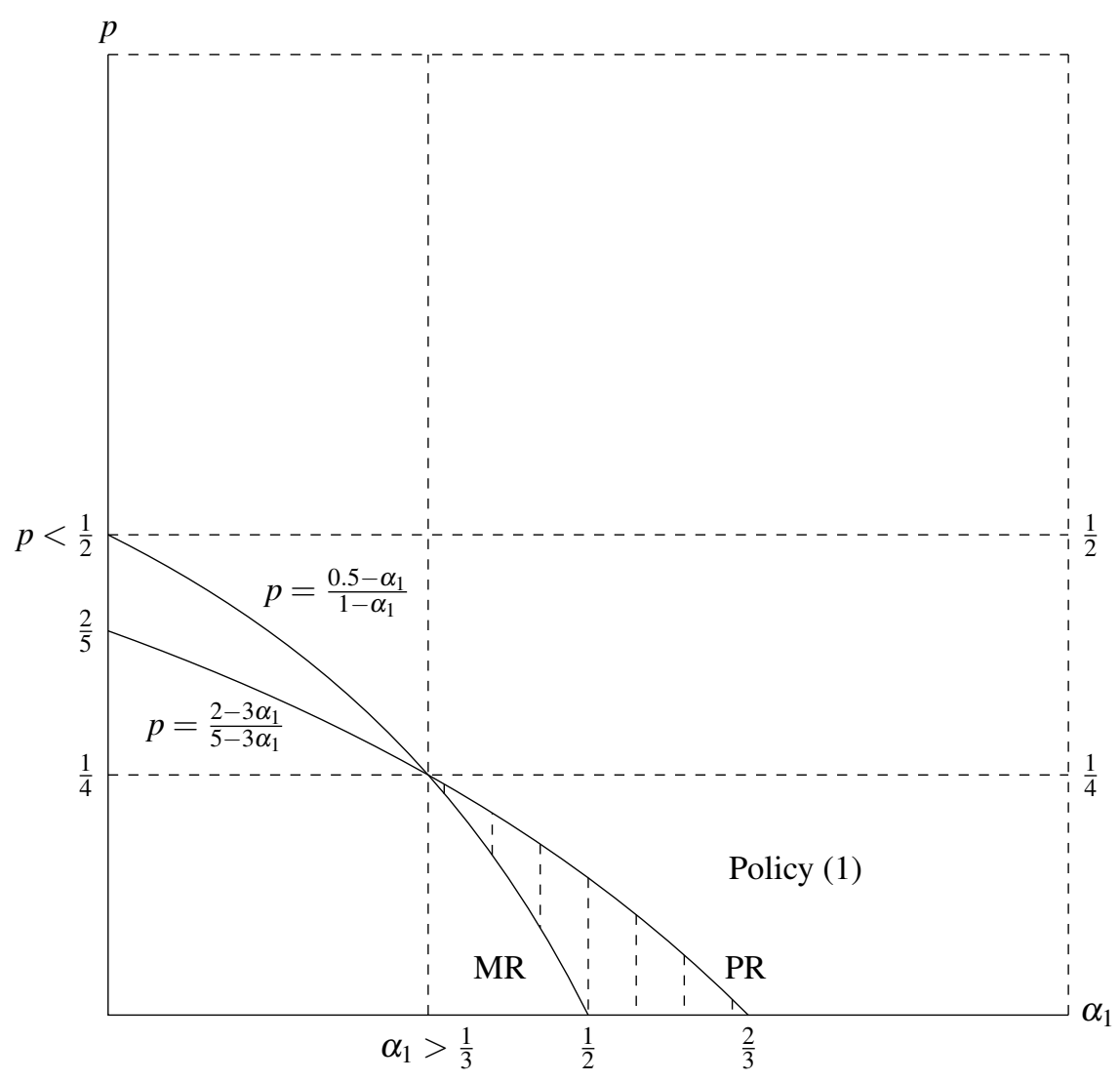

Fig. 1: Under PR, Party $X$ may or may not prefer an industrial policy favouring industry 1 .

\subsection{Proportional Representation Systems}

Under the proportional representation system, there is only one single electoral district that encompasses $A$ and $B$, and the seats will be allocated according to the vote shares without any minimum threshold. Without any industrial policy, the proportion of voters who vote for Party $X$ is 0.5 , and thus each party obtains one seat in the national-wide election.

If Party $X$ adopts Policy (1), the number of seat won will be:

$$
\begin{aligned}
S_{P R} & =\alpha_{1}+\beta_{1}+p\left(1-\alpha_{1}\right)+p\left(1-\beta_{1}\right) \\
& =\alpha_{1}+\frac{1}{3}+p\left(1-\alpha_{1}\right)+\frac{2}{3} p
\end{aligned}
$$

Under PR, Party $X$ prefers Policy (1) to none if

$$
\begin{aligned}
\alpha_{1}+\frac{1}{3}+p\left(1-\alpha_{1}\right)+\frac{2}{3} p & >1 \\
p & >\frac{2-3 \alpha_{1}}{5-3 \alpha_{1}} .
\end{aligned}
$$

Figure 1 illustrates the inequalities (3) and (5). We focus on the range of values of $\alpha_{1}$ above $1 / 3$. Above each curve, Policy (1) is preferred to no industrial policy under its corresponding electoral rule. If $p>1 / 4$, Policy (1) always dominates no industrial policy, regardless of the electoral rule. If $p<1 / 4$, the condition of PR lies above that of MR, implying that the ranges of values of $\alpha_{1}$ and $p$ in which Policy (1) is preferred under PR are smaller than those under MR. In other words, there exists an area of combinations of $\alpha_{1}$ and $p$, shaded in Figure 1, where Policy (1) is preferred under MR but not under PR. 
This simple model illustrates the essence of the decision of adopting an industrial policy. Proportional representation encourages the incumbent party to avoid favouritism that alienates some groups. On the other hand, industrial policies may help the incumbent government to secure more than half of the seats under the majoritarian rule. One way to understand the logic is to interpret the model from the perspective of marginal cost and benefit analysis. The marginal benefit of adopting Policy (1) under MR is larger than that under PR because obtaining a seat under MR, i.e. passing 50\% threshold in a district, is more attainable than achieving the same under PR, i.e. obtaining $50 \%$ of total votes in the nation-wide election. On the other hand, the cost of favouritism under MR is smaller as once the party obtains a seat in a district thanks to an industrial policy, the negative cost can be ignored in the consideration. While under PR, the negative effect applies to the whole nation-wide election and impacts on the overall vote share.

Although the model is not a path-breaking contribution as a similar conclusion has already been told by Persson and Tabellini (1999. 2004), this simple model makes our paper self-contained and highlights an important tradeoff facing the incumbent government. Majoritarian rule motivates the incumbent government to adopt an exclusive policy as the rule allocates a seat to the party given $50 \%$ of the votes in a district. Given the same amount of the votes, the party only gains $25 \%$ of the seats under proportional representation.

\section{Data}

We construct an unbalanced panel dataset consisting of 22,458 observations of 61 International Standard Industrial Classification (ISIC) operating in 55 countries over the period 1990-2010. We collect information on industries from the UNIDO Industrial Statistics Database (INDSTAT4) at a 3 digit-level (2010, revision 3). UNIDO provides data on manufacturing output in current international US dollars that we convert into real US dollars (constant US dollars 2010) terms.

Our dependent variable is the annual growth rate of output of industry $i$ in country $c$ of year $t$. Existing literature on the effects of political institutions, such as democracy, presidentialism or electoral rules, on the economic performance of countries commonly took per capita GDP/income growth as the dependent variable (Persson and Tabellini, 2006, Grier, 2008; Knutsen, 2011). Hence, to be able to compare our results with previous findings at the aggregate level, we use output growth rates at either annual or five-year non-overlapping periods at the industry-level, rather than the output level itself. The meta-analysis of the economic growth effects of democracy in Colagrossi et al. (2020) shows how empirical models use either growth rates and levels to study the economic impact of political institutions. While both techniques are accurate, the former informs about economic growth while the latter informs about production level. Previous meta-analysis of democracy in economic growth shows that the use of growth rates as the dependent variable is commonplace in political economy literature (Doucouliagos and Ulubaşoğlu. 2008).

Data on electoral systems is collected from Bormann and Golder (2013), who provide information on 212 democratic national-level lower-chamber legislative elections taken place in the 55 countries over 1990-2010. All the countries included in the sample are classified as democratic regimes in the sense of Przeworski $(2000)^{5}$ The vast majority of the countries are parliamentary democracies, and others are semi-presidential and presidential democracies. Our classification of electoral systems follows Golder (2005), in which they are typified into three categories of rules: majoritarian, proportional representation and mixed systems. Table A.1 in the Appendix lists the sample countries sorted by electoral systems, and includes any electoral switches and the year those changes took place. Following Bormann and Golder (2013), we construct a dichotomous variable which equals one if legislators are elected on the basis of a majoritarian rules, otherwise the value is zero. For non-electoral years, we input the same value of the previous electoral year. We group mixed systems and PR together because both of

\footnotetext{
5 A regime is deemed democratic when the following conditions hold simultaneously: i) the chief of the executive is elected, ii) the legislature is elected, iii) there is more than one party running the elections and iv) an alternation under the identical electoral rule has taken place.
} 
them depart from majoritarian rules in the sense that they aim at introducing smaller parties into a parliament ${ }^{6}$ Subsequent sections describe the control variables used in our empirical investigation, and Table A.3 in Appendix provides data sources.

\section{Empirical Analysis}

\subsection{Specification}

We first test if electoral rules differ in their impacts on industrial growth. Next, we check if the effect is contingent on the employment size of the industry.

Since we have a panel dataset, we could control for country-industry specific and unobservable factors using fixed-effect estimation. However, changes of electoral rules are rare. It makes a precise estimation of the impact of electoral rules difficult. To tackle this problem, we first estimate the effect by random-effect model and then follow the two-step fixed-effect estimation proposed by Pesaran and Zhou (2018) to make sure that the result is robust.

To test the second hypothesis, we rely on including an interaction term between majoritarian rule (vs nonmajoritarian rule) and employment size. The interaction term will help us discern if the two types of rules are significantly different in terms of the impact on industries. Our preferred regression strategy is to regress annual growth rate or five-year panel growth rate using panel estimation. As suggested in Acemoglu et al. (2015), working with five-year panel, that takes an observation every five years, is preferable to taking averages, which induces serial correlation and makes consistent estimation difficult. We also provide a cross-sectional regression at country-industry level as a robustness check. Although we can control for country-industry specific effects by either random or fixed-effect estimation, it is not what we should do to test our hypothesis. As we theorize that any impact of electoral rule on industries comes from the decision of a government to favour certain industries at a time, controlling for country-industry specific effects would filter our any time-persistent favouritism. The estimation of the coefficient of the interaction term is thus driven by any changes of employment size over time net of any year fixed effects. We thus pool country-industry observations but control for country specific effects by either random or fixed-effect estimations.

Precisely, we estimate the following baseline model:

$$
\begin{gathered}
\text { growth }_{i c, t+1}=\beta_{0}+\beta_{1} M R_{c t}+\beta_{2} \text { Employ }_{i c t}+\mathbf{x}_{i c t}^{\prime} \gamma+\delta_{i c}+\mu_{t}+\varepsilon_{i c t} \\
\text { growth }_{i c, t+1}=\frac{\text { output }_{i c, t+1}-\text { out }_{\text {put }}}{\text { out } t} \\
i=\text { industry }, c=\text { country, } t=\text { year }
\end{gathered}
$$

where the dependent variable is the annual growth rate of output in industry $i$, in country $c$ and year $t$. Note that output growth is computed using the one-year lead so that all explanatory variables are effectively lagged by a period. We place emphasis on the explanatory variables $M R_{c t}$, which is a dichotomous variable for which value one refers to majoritarian, and zero otherwise, and Employ ${ }_{i c t}$, which measures the size of industries in terms of the percentage of employment size (number of workers divided by total population). The term $\mathbf{x}_{i c t}^{\prime}$ is a set of control variables. The yearly fixed effect and country-industry specific effects are captured by $\mu_{t}$ and $\delta_{i c}$. The random error term $\varepsilon_{i c t}$ is assumed to have zero mean.

\footnotetext{
6 We do not find PR and mixed systems present significant differences in the following estimations. We follow reference literature and group together PR and mixed systems (Knutsen 2011).
} 
We first estimate equation (6) by a random-effect model, which assumes that the country-industry specific factor $\delta_{i c}$ does not correlate with other explanatory variables. Next, we modify and employ the two-step fixedeffect estimation proposed by Pesaran and Zhou (2018). The first step is to estimate equation (6) but take away those slowly changing variables (for examples, $M R_{c t}$, land area, and population) by a fixed-effect model, and obtain the estimates of those fixed effects. The second step is to regress the estimated fixed effects on the average values of those slowly changing variables by OLS. The advantage of this approach is to allow filtering out the unobservable individual-specific factors by fixed-effect estimation while obtaining preciser estimates of timeinvariant or slowing-changing variables. Formally, we estimate the following equation by fixed-effect model:

$$
\text { growth }_{i c, t+1}=\beta_{0}+\beta_{2} \text { Employ }_{i c t}+x_{i c t}^{\prime} \gamma+\delta_{i c}+\mu_{t}+\varepsilon_{i c t}
$$

Obtain $\overline{\delta_{i c}}$ and regress:

$$
\overline{\delta_{i c}}=b_{0}+b_{1} \text { average } M R_{c}+b_{2} \text { average_ln_Area }+b_{3} \text { average_ln_Pop } p_{c}+e_{i c}
$$

This approach may suffer from a deficiency that the sample size of the second step could be small. Fortunately, we have more than 2,361 country-industries and thus the result of the OLS can be confidently relied upon.

To test our second hypothesis that concerns the correlation between growth rate and employment size, we estimate the following equation:

$$
\text { growth }_{i c, t+1}=\beta_{0}+\beta_{1} M R_{c t}+\beta_{2} \text { Employ }_{i c t}+\beta_{3} M R_{c t} \text { Employ }_{i c t}+\mathbf{x}_{i c t}^{\prime} \gamma+\eta_{c}+\mu_{t}+\varepsilon_{i c t}
$$

A significant coefficient associated with the interaction $\left(\beta_{3}\right)$ would mean that any correlation between majoritarian electoral rule and industrial growth varies with respect to the employment size. We now control for country specific effects $\eta_{c}$ instead of country-industry effects.

In all the specifications we exclude observations having a growth rate greater than one, eliminating any possibilities that the results are driven by some extreme growth values.

\subsection{Control variables}

We control for country-level economic development $\left(G D P_{c t}\right)$ and the output of total manufacturing sector $\left(M a n u_{c t}\right.$ (the sum of outputs of all industries available in our data), both in real terms (constant US dollars, 2010), and their growth rates in the current year 7 The variables at levels are logarithmic-transformed before including in the regression while the growth rates are computed by the percentage change formula.

To control for the financial potential of industries, we collect data on shares of value added of industries to total manufacturing sector (Share_VA $A_{\text {ict }}$ ). By so doing, we attempt to control for convergence-type effects in industry growth (see Rodrik (2012) for further insights). From a political economy literature viewpoint, the inclusion of the share of value added helps to control for the financial strength of each industry to sway the decision-making process of policies in their favour. Put it differently, we try to keep constant the lobbying ability of industries. However, since there is no available data on the lobbying effort, we cannot formulate a proper channel nor an argument based on the lobbying capacity of industries.

We include the level of education of the population (HumanCapital ${ }_{c t}$ ) to control for human capital externalities both in economic growth and political dimensions, such as political stability and the civil monitoring of policymaking (Lucas, 1988, Glaeser et al. 2004: Alesina et al., 1996). We also control for different levels of institutional quality which could either shape the political process in a country or determine the industry growth rates. Based on the Freedom House rating of civil liberties ( CivilLiberties $_{c t}$ ), we include a re-scaled variable of the original

\footnotetext{
${ }^{7}$ Note that our dependent variable is the one-year lead industrial growth rate.
} 
one which ranges from 1 (the lowest of civil liberties) to 7 (the highest) ${ }^{8}$ We also control for openness -import plus export ratio- and average tariff on manufacturing products provided by World Bank. Openness $\left(\right.$ Openness $\left._{c t}\right)$ measures how important the trade sector is, or how much the economy is reliant on international trade, which may in turn influence the government's preference on industrial policy. Average tariff (Tarif $\left.f_{c t}\right)$ captures the overall level of protectionism adopted by a government. The remaining effect of the electoral rule can thus hint on the preference of a government towards certain industries holding the overall protectionism position constant.

Considering previous findings on the interplay between electoral systems and population size (Rogowski, 1987, Rokkan, 1970, Blais and Massicotte, 1997), we include the log of total population ( $\left.l n_{-} P o p_{c t}\right)$. We consider also the size of the countries ( $\ln$ Area $_{c t}$, log of land area in sq. km provided by World Bank Database). Geography could crucially determine the economic outcome of alternative electoral rules (Blais and Massicotte, 1997, McGillivray, 2018, Rickard, 2012a). Table 1 provides some summary statistics of the variables while countrylevel information is relegated to the Appendix, with mean values on key variables over the period 1990-2010 (Table A4).

Table 1: Summary statistics

\begin{tabular}{lccccc}
\hline \hline \multicolumn{1}{c}{ Variable } & Mean & Std. Dev. & Min. & Max. & N \\
\hline Growth Rate & 0.058 & 0.378 & -1 & 0.9965 & 17087 \\
MR & 0.1576 & 0.3644 & 0 & 1 & 17087 \\
Employment & 0.0013 & 0.0019 & 0 & 0.0626 & 17087 \\
ln Manu Output & 24.4802 & 2.0280 & 18.2370 & 29.0316 & 17087 \\
Manu Output Growth & 0.1846 & 0.5771 & -0.6510 & 3.6286 & 17087 \\
ln GDP & 26.4014 & 1.8200 & 22.1863 & 30.3251 & 17087 \\
GDP growth & 0.0304 & 0.03313 & -0.1481 & 0.1258 & 17087 \\
Share VA & 0.0198 & 0.0280 & 0 & 0.5649 & 17087 \\
Civil Liberties & 6.2418 & 0.8938 & 3 & 7 & 17087 \\
Human Capital & 0.9903 & 0.1803 & 0.1608 & 1.5661 & 17087 \\
ln Population & 16.5675 & 1.5116 & 13.7571 & 20.8843 & 17087 \\
ln Area & 12.2467 & 1.6036 & 7.6158 & 16.0306 & 17087 \\
Openness & 74.0701 & 33.4530 & 16.7497 & 175.1743 & 17087 \\
Tariff & 3.9574 & 4.4646 & 0.11 & 32.75 & 17087 \\
Gallagher Index & 6.4704 & 5.3417 & 0.42 & 33.25 & 16293 \\
\hline
\end{tabular}

\subsection{Results}

Before we test if the effect of a country's electoral rule is contingent on industrial employment, we check if electoral rules have any significant impacts on manufacturing industries. One concern is that electoral rules do not vary frequently. For most of the countries in our sample, the binary MR indicator did not change over the period of our study. The lack of variation may render the coefficient of MR of a fixed-effect estimation unreliable because it is driven by those infrequent changes. Acknowledging this limitation, we explore two different approaches trying to deliver a more reliable conclusion.

Table 2 presents evidence suggesting that MR may unleash a negative effect in the economic performance of industries. Column 1 is a random-effect estimation with MR binary indicator $\left(M R_{c t}\right)$ and employment size $\left(\right.$ Employ $\left._{i c t}\right)$ included, while controlling for year fixed effects. Majoritarian rules are negatively correlated with industrial growth, i.e. manufacturing industries tend to grow slower under MR. This result alone is interesting since most of the research in this area studied the impact of electoral rules on the aggregate output (i.e. various

\footnotetext{
8 We have conducted models including alternative measures of democracy. Drawing on Knutsen (2011), we have considered the Polity2 index of the Polity IV Project, which brings similar results as those displayed in the paper.
} 
measures related to GDP). As far as we research, previous literature has not provided any quantitative attempt to study the impact of electoral rules on manufacturing industries from a disaggregated approach as taken here. Our results suggest that growth rate is $2.67 \%$ lower under MR. Industry's employment size enter the model with a negative sign, which is not surprising since bigger industries may suffer from substantial diminishing returns to scale.

Column 2 of Table 2 includes also countries' characteristics (population and area of land), the share of valueadded of the industry, as well as total output of the manufacturing sector, GDP, and their growth rates. The share of value-added is associated with a negative sign, which is consistent with the convergence hypothesis (Barro and Sala-i Martin, 1997). Total manufacturing output is negative but its growth rate is positive, indicating that an overall humped-shaped growth trajectory, i.e. industries grow slower when the manufacturing sector is large but overall growth drives individual industry growth in the short-run. Meanwhile, majoritarian indicator remains negative. Column 3 reports the model that controls for civil liberties, human capital and also trade-related variables (openness and average tariff level). The result is similar. Civil liberties, human capital and openness are all positively correlated with industrial growth. Column 4 replicates Column 3 but changing the estimation method to fixed-effect model at country-industry level. Majoritarian indicator remains negative and the magnitude is perhaps too big. Note that population and area have been discarded.

Next, we employ the Fixed Effects Filtered (FEF) estimator proposed by Pesaran and Zhou (2018). The implementation is simple: first we regress the dependent variable (industrial output growth) on a set of timevarying variables with a fixed-effect model, and then regress the average combined residuals (fixed effects and the residuals) over the period obtained in the first stage on time-invariant variables together with a constant term by OLS 9 A slight modification is done to suit our data: we do not consider MR as a time-varying variable but regress the fixed effects obtained in the first stage on the mean value of the MR variable over time. Together with the average MR, we also include average population, the log of land area of the country in the second stage. Column 5 (Table 2) shows the first stage of the FEF estimation, where majoritarian indicator, population and land area are taken away. In Column 6, we regress the estimated fixed effects from the fixed-effect estimation of Column 5 on the average majoritarian indicator, population and land area. However, we now do not find MR correlated with industrial output growth while the signs of population and land area are consistent. In short, we do not find robust result showing that MR and industrial growth are negatively correlated.

The previous step serves as a prelude of the following. Why or is it true that MR leads to persistent negative impact on the manufacturing industries? If MR has a systematic negative impact on manufacturing industries, they would diminish in production over time and we would observe that MR countries are associated with larger service sectors. As far as we know, there is no academic evidence documenting this phenomenon. It is thus necessary to investigate if an industry-level phenomenon has been covered; electoral rule may impact on industries differently. We thus interact MR indicator with industry's employment size. The interaction term in equation (9) is the variable of focus. The lack of variation of MR becomes less a problem as we are mainly concerned with the difference in the marginal effect of industry employment under MR and non-MR regimes.

Another more subtle consideration, which affects the choice of estimation, is that our model illustrates potential favouritism towards certain industries by the government within a country at a point of time. Using fixed-effect panel estimation at country-industry level implies utilizing only the within variation to estimate the coefficients, meaning that the time-persistent favouritism has been removed by the fixed effects. A correct estimation should be able to detect favouritism among industries and thus between-industry variation within a country is the information to exploit. Meanwhile, controlling for country fixed effects help putting industries in different countries on the same page for comparison. Therefore, we adopt the following strategy. Refer to Column 1 of Table 3 , we regress industrial growth rate on the same set of explanatory variables allowing random effects at country level but pooling industries within a country ${ }^{10}$ We find that the interaction term is positive and significant, consistent with what our

\footnotetext{
${ }^{9}$ Fixed effects by definition are time-invariant and thus the second stage is done on the one-country-industry one-observation basis

10 It was done with Stata mixed command that relies on maximum likelihood estimation.
} 
Table 2: Electoral Rules and Industry Growth

\begin{tabular}{|c|c|c|c|c|c|c|}
\hline & $\begin{array}{l}(1) \\
\mathrm{RE}\end{array}$ & $\begin{array}{l}(2) \\
\mathrm{RE}\end{array}$ & $\begin{array}{l}(3) \\
\mathrm{RE}\end{array}$ & $\begin{array}{l}\text { (4) } \\
\text { FE }\end{array}$ & $\begin{array}{c}(5) \\
F E F(1)\end{array}$ & $\begin{array}{c}(6) \\
F E F(2)\end{array}$ \\
\hline MR & $\begin{array}{c}-0.0267^{* * *} \\
(0.0048)\end{array}$ & $\begin{array}{c}-0.0339^{* * *} \\
(0.0059)\end{array}$ & $\begin{array}{c}-0.0253^{* * *} \\
(0.0058)\end{array}$ & $\begin{array}{c}-0.0959^{* * *} \\
(0.0175)\end{array}$ & & $\begin{array}{l}-0.0001 \\
(0.0159)\end{array}$ \\
\hline Industry Employ & $\begin{array}{c}-4.0883^{* * *} \\
(1.3565)\end{array}$ & $\begin{array}{l}-0.2536 \\
(1.1685)\end{array}$ & $\begin{array}{l}-1.3881 \\
(1.2501)\end{array}$ & $\begin{array}{c}-16.9885^{\text {*** }} \\
(6.3470)\end{array}$ & $\begin{array}{c}-17.2259^{* * *} \\
(6.3486)\end{array}$ & \\
\hline ln Manu Output & & $\begin{array}{c}-0.0283^{* * *} \\
(0.0053)\end{array}$ & $\begin{array}{c}-0.0419^{* * *} \\
(0.0059)\end{array}$ & $\begin{array}{c}-0.1103^{* * *} \\
(0.0140)\end{array}$ & $\begin{array}{c}-0.1154^{* * *} \\
(0.0140)\end{array}$ & \\
\hline Lag Manu Growth & & $\begin{array}{c}0.0531^{* * *} \\
(0.0111)\end{array}$ & $\begin{array}{c}0.0417^{* * *} \\
(0.0123)\end{array}$ & $\begin{array}{c}0.0525^{* * *} \\
(0.0136)\end{array}$ & $\begin{array}{c}0.0541^{* * *} \\
(0.0136)\end{array}$ & \\
\hline $\ln$ GDP & & $\begin{array}{c}0.0278^{* * *} \\
(0.0061)\end{array}$ & $\begin{array}{c}0.0248^{* * *} \\
(0.0074)\end{array}$ & $\begin{array}{c}0.0154 \\
(0.0367)\end{array}$ & $\begin{array}{c}0.0099 \\
(0.0366)\end{array}$ & \\
\hline Lag GDP Growth & & $\begin{array}{c}0.3960^{* * *} \\
(0.0653)\end{array}$ & $\begin{array}{c}0.5252^{* * *} \\
(0.0765)\end{array}$ & $\begin{array}{c}0.4710^{* * *} \\
(0.0856)\end{array}$ & $\begin{array}{c}0.4701^{* * *} \\
(0.0857)\end{array}$ & \\
\hline Share VA & & $\begin{array}{c}-0.2516^{* * *} \\
(0.0899)\end{array}$ & $\begin{array}{l}-0.1250^{*} \\
(0.0720)\end{array}$ & $\begin{array}{c}-3.3305^{* * *} \\
(0.3689)\end{array}$ & $\begin{array}{c}-3.3214^{* * *} \\
(0.3683)\end{array}$ & \\
\hline $\ln$ Pop & & $\begin{array}{c}0.0117^{* * *} \\
(0.0027)\end{array}$ & $\begin{array}{c}0.0335^{* * *} \\
(0.0049)\end{array}$ & & & $\begin{array}{c}0.1573^{* * *} \\
(0.0057)\end{array}$ \\
\hline ln Area & & $\begin{array}{c}-0.0102^{* * *} \\
(0.0018)\end{array}$ & $\begin{array}{l}-0.0003 \\
(0.0019)\end{array}$ & & & $\begin{array}{c}-0.0104^{* *} \\
(0.0047)\end{array}$ \\
\hline Civil Liberties & & & $\begin{array}{c}0.0101^{* * *} \\
(0.0035)\end{array}$ & $\begin{array}{c}0.0136^{* * *} \\
(0.0051)\end{array}$ & $\begin{array}{l}0.0129^{* *} \\
(0.0051)\end{array}$ & \\
\hline Human Capital & & & $\begin{array}{c}0.0548^{* * *} \\
(0.0145)\end{array}$ & $\begin{array}{l}0.0400^{* *} \\
(0.0196)\end{array}$ & $\begin{array}{c}0.0435^{* *} \\
(0.0196)\end{array}$ & \\
\hline Openness & & & $\begin{array}{c}0.0008^{* * *} \\
(0.0001)\end{array}$ & $\begin{array}{c}0.0029^{* * *} \\
(0.0003)\end{array}$ & $\begin{array}{c}0.0030^{* * *} \\
(0.0003)\end{array}$ & \\
\hline Tariff Manu & & & $\begin{array}{l}-0.0002 \\
(0.0006)\end{array}$ & $\begin{array}{l}-0.0024^{*} \\
(0.0013)\end{array}$ & $\begin{array}{l}-0.0022^{*} \\
(0.0013)\end{array}$ & \\
\hline Constant & $\begin{array}{c}0.3562^{* * *} \\
(0.0331)\end{array}$ & $\begin{array}{c}-0.2058^{* * *} \\
(0.0440)\end{array}$ & $\begin{array}{c}-0.4234^{* * *} \\
(0.0610)\end{array}$ & $\begin{array}{l}2.0155^{* *} \\
(0.8003)\end{array}$ & $\begin{array}{c}2.2634^{* * *} \\
(0.7933)\end{array}$ & $\begin{array}{c}-2.4054^{* * *} \\
(0.0759)\end{array}$ \\
\hline$N$ & 24274 & 21028 & 17087 & 17197 & 17197 & 2361 \\
\hline $\begin{array}{l}\text { No. of Groups } \\
\text { log-likelihood }\end{array}$ & 2699 & 2567 & 2360 & $\begin{array}{l}2361 \\
4790\end{array}$ & $\begin{array}{l}2361 \\
4783\end{array}$ & 50 \\
\hline Within R-squared & 0.6931 & 0.7122 & 0.7271 & 0.7348 & 0.7346 & \\
\hline Between R-squared & 0.4679 & 0.5380 & 0.5640 & 0.0762 & 0.0691 & \\
\hline Overall R-squared & 0.6587 & 0.6827 & 0.6998 & 0.4034 & 0.3970 & 0.4967 \\
\hline
\end{tabular}

Standard errors clustering at country-industry level in parentheses

${ }^{*} p<.1,{ }^{* *} p<.05,{ }^{* * *} p<.01$ 
model predicts. Larger industries tend to grow slower under non-MR but such a correlation is absent under MR. The Chi-squared test that employment is positively correlated with industrial growth is however 0.16 , implying that we cannot conclude that larger industries grow faster under MR.

Column 2 of Table 3 instead controls country fixed effects. Again, output growth is slower for larger industries in non-MR countries but such a negative correlation is absent in MR countries. Under non-MR rules, a $1 \%$ increase in employment size is correlated with $0.043 \%$ decrease in output growth. However, the same increase in employment size under MR is correlated with $0.0056 \%$ increase in growth, which is statistically insignificant. The association between lower growth rate and larger employment size under non-MR rules may be because larger industries tend to be more established and have already passed the period of fast growth compared to smaller industries. Such an economic intuition is however not applicable in MR countries. The explanation our work suggests is that majoritarian rule provides incentive for governments to target large industries and their associated voters within the economy. Moreover, though not directly testable with our data, the lower overall industrial growth rate under MR may also be due to the favouritism that creates an uneven playing field.

Column 3-4 include random effects of country-industries while assuming either country random or fixed effects. We find the coefficient of the interaction term ranges from 5.35 to 5.44, roughly of the same magnitude of Column 1 and 2. Column 5 instead controls for country-industry fixed effects, implying the coefficients are driven by variation over time. The coefficient of the interaction term is too large to be reliable.

On the surface, the economic magnitude seems small as industries are on average small in employment size 11 However, compounded growth of even a small percentage a year could lead to a substantial difference between the targeted and the left-out. For instance, industry A is larger than industry B in terms of employment size by $1 \%$ of the population and their outputs are at the same level. After 5 years, holding other factors constant, their output difference will be $2.17 \%$, while not taking into account possible increase in employment size of industry A.

\section{Sensitivity Checks}

6.1 Alternative measures of electoral rules: Disproportionality index

Taagepera and Qvortrup (2012) warn that a dichotomous characterization of majoritarian versus proportional systems falls short of capturing potential overlapping institutional features across electoral systems. Similarly, Blais et al. (2017) suggests that while using a dummy variable is the simplest and most direct, it is also the crudest indicator. Their work combines the use of a dummy variable to measure proportional representation systems with the Gallagher index of disproportionality. The Gallagher index is an encompassing measure of the degree to which the distribution of seats in the legislature departs from the distribution of votes and is widely used to measure disproportionality in parliaments and as an alternative measure of electoral rules (Gallagher, 1991). We check the robustness of our result by replacing the binary MR indicator by the Gallagher index of parliaments that presents higher variability across time and within electoral rules.

The index is computed as follows:

$$
\text { GallagherIndex }=\sqrt{\frac{1}{2} \sum\left(v_{i}-s_{i}\right)^{2}}
$$

where $v_{i}$ is the share of votes in legislative elections and $s_{i}$ the share of seats in parliament of a each political party $(i=1, \ldots ., n$ political parties). The Gallagher index is interpreted as the disproportionality between vote and seats in parliaments. Theoretically, it can span within a 0-100 interval, where the lower the value, the higher the

\footnotetext{
11 As the World Bank sector definition is rather fine-grained, the average employment size is $0.1 \%$ of population. But it is intuitive to assume that those "small" industries could be combined at a higher level and constitute a substantial group and be targeted by the government.
} 
Table 3: Effect of MR Contingent on Employment Size

\begin{tabular}{|c|c|c|c|c|c|}
\hline & $(1)$ & $(2)$ & (3) & (4) & $(5)$ \\
\hline Country-Industry & Pooled & Pooled & RE & $\mathrm{RE}$ & $\mathrm{FE}$ \\
\hline Country & RE & FE & RE & $\mathrm{FE}$ & NA \\
\hline MR & $\begin{array}{c}-0.0732^{* * *} \\
(0.0277)\end{array}$ & $\begin{array}{c}-0.1077^{* * *} \\
(0.0176)\end{array}$ & $\begin{array}{c}-0.0746^{* * *} \\
(0.0278)\end{array}$ & $\begin{array}{c}-0.1078^{* * *} \\
(0.0176)\end{array}$ & $\begin{array}{c}-0.1510^{* * *} \\
(0.0204)\end{array}$ \\
\hline IndustryEmploy & $\begin{array}{c}-4.1454^{* * *} \\
(1.5791)\end{array}$ & $\begin{array}{c}-4.3335^{* * *} \\
(1.2532)\end{array}$ & $\begin{array}{c}-4.6146^{* * *} \\
(1.6898)\end{array}$ & $\begin{array}{c}-4.7318^{* * *} \\
(1.2793)\end{array}$ & $\begin{array}{c}-23.8611^{* * *} \\
(5.1658)\end{array}$ \\
\hline MR $\times$ IndustryEmploy & $\begin{array}{l}4.7104^{* *} \\
(2.1076)\end{array}$ & $\begin{array}{c}4.8951^{* * *} \\
(1.6023)\end{array}$ & $\begin{array}{l}5.3495^{* *} \\
(2.2116)\end{array}$ & $\begin{array}{c}5.4385^{* * *} \\
(1.6255)\end{array}$ & $\begin{array}{c}42.4942^{* * *} \\
(5.2377)\end{array}$ \\
\hline In Manu Output & $\begin{array}{c}-0.0688^{* * *} \\
(0.0230)\end{array}$ & $\begin{array}{c}-0.0844^{* * *} \\
(0.0134)\end{array}$ & $\begin{array}{c}-0.0707^{* * *} \\
(0.0231)\end{array}$ & $\begin{array}{c}-0.0861^{* * *} \\
(0.0133)\end{array}$ & $\begin{array}{c}-0.1178^{* * *} \\
(0.0141)\end{array}$ \\
\hline Lag Manu Growth & $\begin{array}{l}0.0474^{* *} \\
(0.0198)\end{array}$ & $\begin{array}{c}0.0468^{* * *} \\
(0.0134)\end{array}$ & $\begin{array}{l}0.0477^{* *} \\
(0.0198)\end{array}$ & $\begin{array}{c}0.0471^{* * *} \\
(0.0134)\end{array}$ & $\begin{array}{c}0.0539^{* * *} \\
(0.0136)\end{array}$ \\
\hline $\ln$ GDP & $\begin{array}{l}0.0573^{*} \\
(0.0309)\end{array}$ & $\begin{array}{l}-0.0070 \\
(0.0366)\end{array}$ & $\begin{array}{l}0.0591^{*} \\
(0.0311)\end{array}$ & $\begin{array}{l}-0.0058 \\
(0.0363)\end{array}$ & $\begin{array}{c}0.0274 \\
(0.0367)\end{array}$ \\
\hline Lag GDP Growth & $\begin{array}{l}0.5038^{* *} \\
(0.1965)\end{array}$ & $\begin{array}{c}0.5273^{* * *} \\
(0.0817)\end{array}$ & $\begin{array}{l}0.5012^{* *} \\
(0.1967)\end{array}$ & $\begin{array}{c}0.5254^{* * *} \\
(0.0815)\end{array}$ & $\begin{array}{c}0.4715^{* * *} \\
(0.0859)\end{array}$ \\
\hline Share VA & $\begin{array}{c}0.1969^{* * *} \\
(0.0622)\end{array}$ & $\begin{array}{c}0.2032^{* * *} \\
(0.0577)\end{array}$ & $\begin{array}{c}0.1684^{* * *} \\
(0.0626)\end{array}$ & $\begin{array}{c}0.1791^{* * *} \\
(0.0581)\end{array}$ & $\begin{array}{c}-3.3228^{* * *} \\
(0.3756)\end{array}$ \\
\hline Civil Liberties & $\begin{array}{c}0.0109 \\
(0.0099)\end{array}$ & $\begin{array}{l}0.0121^{* *} \\
(0.0051)\end{array}$ & $\begin{array}{c}0.0110 \\
(0.0098)\end{array}$ & $\begin{array}{l}0.0122^{* *} \\
(0.0050)\end{array}$ & $\begin{array}{c}0.0137^{* * *} \\
(0.0051)\end{array}$ \\
\hline Human Capital & $\begin{array}{c}0.0326 \\
(0.0364)\end{array}$ & $\begin{array}{c}0.0240 \\
(0.0185)\end{array}$ & $\begin{array}{c}0.0330 \\
(0.0363)\end{array}$ & $\begin{array}{c}0.0244 \\
(0.0184)\end{array}$ & $\begin{array}{l}0.0457^{* *} \\
(0.0195)\end{array}$ \\
\hline Openness & $\begin{array}{c}0.0017^{* * *} \\
(0.0005)\end{array}$ & $\begin{array}{c}0.0025^{* * *} \\
(0.0003)\end{array}$ & $\begin{array}{c}0.0017^{* * *} \\
(0.0005)\end{array}$ & $\begin{array}{c}0.0025^{* * *} \\
(0.0003)\end{array}$ & $\begin{array}{c}0.0029^{* * *} \\
(0.0003)\end{array}$ \\
\hline Tariff & $\begin{array}{l}-0.0007 \\
(0.0022)\end{array}$ & $\begin{array}{c}-0.0024^{* *} \\
(0.0011)\end{array}$ & $\begin{array}{l}-0.0007 \\
(0.0022)\end{array}$ & $\begin{array}{c}-0.0024^{* *} \\
(0.0011)\end{array}$ & $\begin{array}{c}-0.0029^{* *} \\
(0.0012)\end{array}$ \\
\hline $\ln$ Pop & $\begin{array}{c}0.0501^{* * *} \\
(0.0193)\end{array}$ & & $\begin{array}{c}0.0511^{* * *} \\
(0.0194)\end{array}$ & & \\
\hline ln Area & $\begin{array}{l}-0.0032 \\
(0.0091)\end{array}$ & & $\begin{array}{l}-0.0034 \\
(0.0092)\end{array}$ & & \\
\hline Constant & $\begin{array}{c}-0.9003^{* * *} \\
(0.2583)\end{array}$ & $\begin{array}{l}1.5782^{* *} \\
(0.7054)\end{array}$ & $\begin{array}{c}-0.9165^{* * *} \\
(0.2625)\end{array}$ & $\begin{array}{l}1.5848^{* *} \\
(0.6998)\end{array}$ & $\begin{array}{l}1.8930^{* *} \\
(0.8018)\end{array}$ \\
\hline$N$ & 17087 & 17197 & 17087 & 17197 & 17197 \\
\hline log-likelihood & 2829 & 2974 & 2834 & 2978 & 4809 \\
\hline Within R-squared & & & & & 0.7354 \\
\hline Between R-squared & & & & & 0.0794 \\
\hline Overall R-Sq & & & & & 0.4090 \\
\hline AIC & -5588 & -5788 & -5596 & -5791 & -9558 \\
\hline
\end{tabular}

Standard errors clustered in countries (Column 1 and 3) and country-industries (2, 4 and 5) in parentheses

${ }^{*} p<.1,{ }^{* *} p<.05,{ }^{* * *} p<.01$ 
proportionality of a parliament. In our sample data, the Gallagher index goes from 0.26 (South Africa, 2004) to 33.25 (Mongolia, 2006). The Gallagher index is collected from Christopher Gandrud database 12

Fig. 2: Evolution of Disproportionality

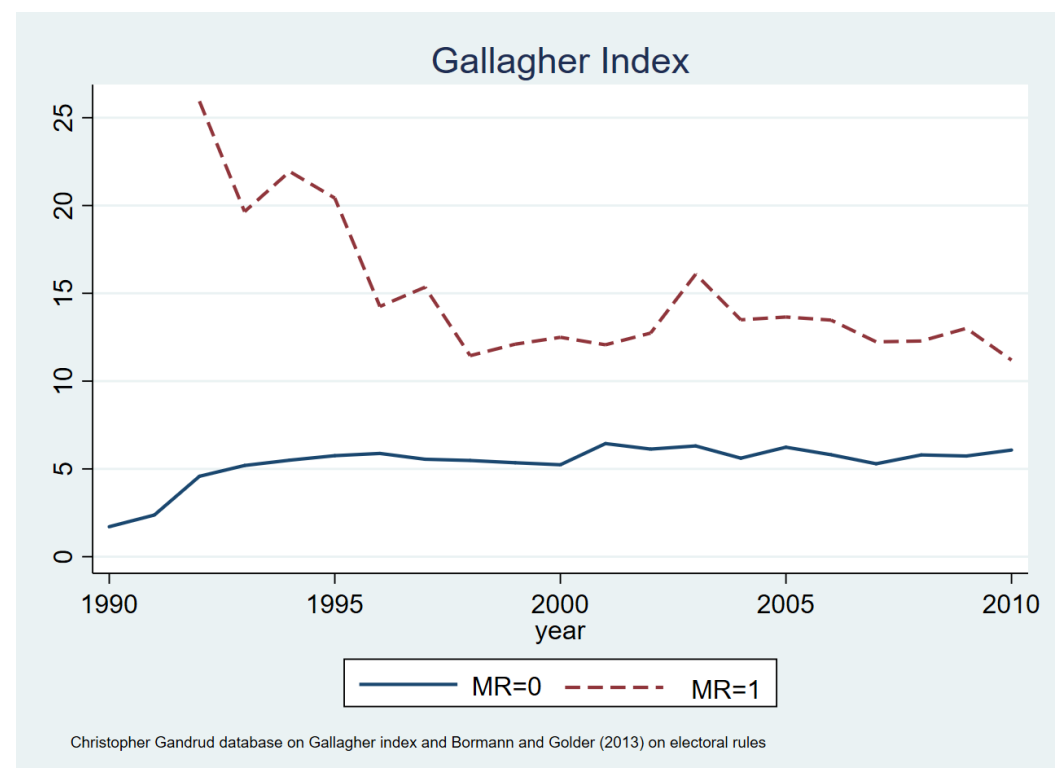

Common wisdom in political science associates majoritarian rules with more disproportional parliaments. Powell (2000) provides a theoretical background and empirical evidence suggesting that proportional representation systems outperform single-member district systems in terms of disproportionality of parliaments. Along a similar line, more recent theoretical and empirical research provides further leverage to the association between constitutional features, such as electoral rules, and disproportionality (Fiva and Folke, 2016; Blais et al. 2017; Pierzgalski, 2018).

Figure 2 shows the evolution of average Gallagher index by majoritarian and non-majoritarian countries of our sample. Over the period 1990-2010 there is a convergence between these two types of parliaments, although nonmajoritarian countries are clearly more proportional in terms of the Gallagher index than majoritarian countries. The average Gallagher index for the set of countries using proportional representation systems is 5.34 while the set of countries using majoritarian rules is 14.94.

Based on the results of Section 5, our prior is that the coefficient associated with disproportionality should be significant and of the same sign as previously associated with MR. Indeed, as shown in Column 1 in Table 4 . the panel estimation, which takes the specification of Column 2 of Table 3 , reveals that higher disproportionality is associated with lower industrial growth. This result is consistent with Alfano and Baraldi (2014), who found a negative growth effect associated with increasing levels of the Gallagher index in an aggregate context. The interaction between disproportionality and industrial employment is positively and significantly correlated with industrial growth, pointing to the same conclusion that employment size under more proportional parliaments is detrimental to growth but such a correlation weakens as proportionality decreases.

Figure 3 plots the marginal effects of industrial employment at different values of Gallagher index. Roughly speaking, when the Gallagher index is lower than 15, a larger employment is a negative factor for growth. Recall that majoritarian rules are associated with higher Gallagher index, the result agrees with those using electoral dichotomous indicator in the previous section.

12 Retrieved at https://github.com/christophergandrud/Disproportionality_Data 
Fig. 3: Marginal Effects of Employment

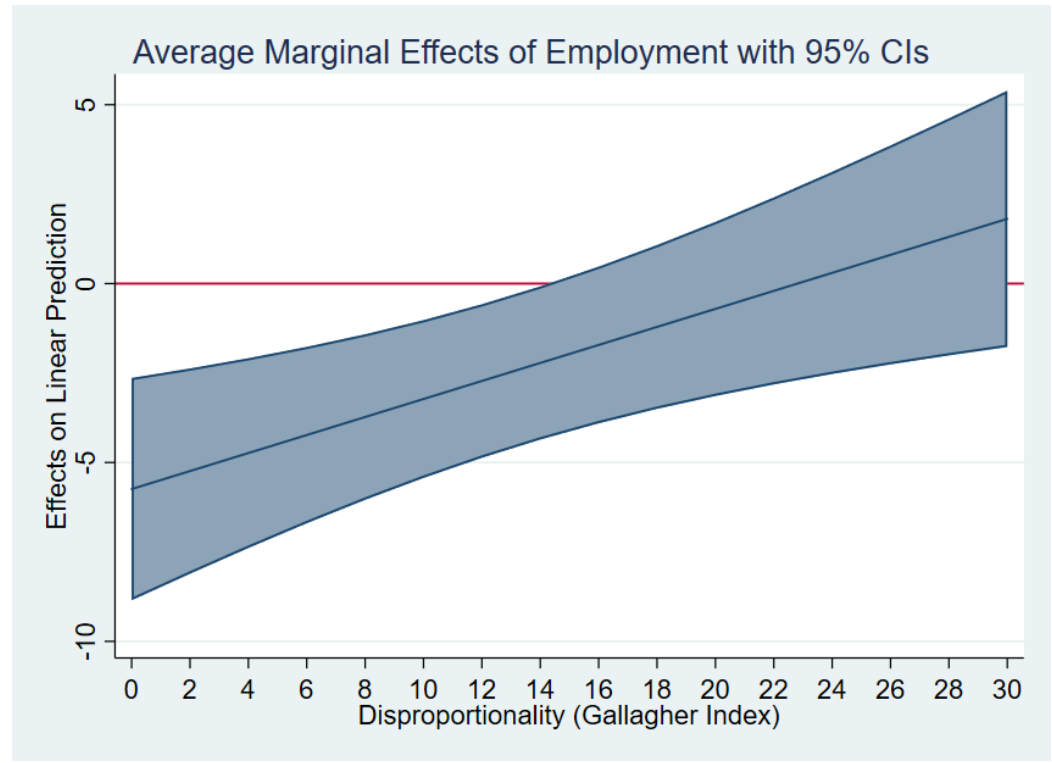

\subsection{Legal Origins}

British legal origin tends to maintain majoritarian rules compared to other origins. Yeung (2017) suggests that electoral rules are endogenously determined and the main reason behind switching to proportional representation by those political elites in the early 20th Century is to avoid mass redistribution by future governments, which would be constrained by constitutions of different political or legal origin. Therefore, our result may not be due to the incentive constraint facing politicians under different electoral rules, but simply because of the division of legal origins, and the associated political and economic characteristics. A robustness check is done by including a binary indicator of British origin or not together with its interactions with MR indicator, employment size and the triple interaction term. Column 2 of Table 4 reports the regression that relies on panel estimation with random effects at country level, which allows estimating the coefficient of legal origin. Figure 4 plots the main results of this regression. First, we find the same result that under non-MR the larger is the employment, the lower is the industrial growth rate and such a correlation is absent under MR, though such a correlation is stronger in countries of British origin. Taking into account legal origin does not refute our hypothesis. Second, larger industries in countries of British legal origin grow faster than smaller industries and the combined marginal effect is substantial as Figure 4 shows. Although this phenomenon is sufficiently interesting, this work does not attempt to investigate further why larger industries in countries of British origin tend to perform better than smaller industries.

\subsection{5-year Growth}

One-year growth rate may not capture the impact of any favourable or unfavourable policies by the government. Column 3 and 4 of Table 4 takes 5-year growth rate as the dependent variable, picks those observations of 2000, 2005 and 2010 only (Manufacturing growth rate and GDP growth rate become 5-year percentage growth), and reestimates the models of Column 1 and 2 of Table 3 using the 5-year interval panel. The interaction term between MR and employment size is positive and significant at $10 \%$ level. 
Table 4: Robustness Checks

\begin{tabular}{|c|c|c|c|c|}
\hline & (1) & (2) & (3) & (4) \\
\hline Country-Industry & Pooled & Pooled & Pooled & Pooled \\
\hline Country & $\mathrm{FE}$ & RE & RE & $\mathrm{FE}$ \\
\hline Gallagher Index & $\begin{array}{l}-0.0020^{*} \\
(0.0010)\end{array}$ & & & \\
\hline Employ & $\begin{array}{c}-5.7434^{* * *} \\
(1.5837)\end{array}$ & $\begin{array}{c}-4.1456^{* * *} \\
(1.6048)\end{array}$ & $\begin{array}{l}-19.3716^{*} \\
(10.0586)\end{array}$ & $\begin{array}{c}-25.4881^{* * *} \\
(9.8059)\end{array}$ \\
\hline GallagherIndex $\times$ Employ & $\begin{array}{c}0.2518^{* * *} \\
(0.0872)\end{array}$ & & & \\
\hline ln Manu output & $\begin{array}{c}-0.0791^{* * *} \\
(0.0136)\end{array}$ & $\begin{array}{c}-0.0679^{* * *} \\
(0.0220)\end{array}$ & $\begin{array}{c}-0.1370 \\
(0.0982)\end{array}$ & $\begin{array}{l}-0.2861 \\
(0.1988)\end{array}$ \\
\hline Lag Manu growth & $\begin{array}{c}0.0447^{* * *} \\
(0.0140)\end{array}$ & $\begin{array}{l}0.0470^{* *} \\
(0.0195)\end{array}$ & $\begin{array}{c}0.4721^{* * *} \\
(0.0701)\end{array}$ & $\begin{array}{c}0.6542^{* * *} \\
(0.1697)\end{array}$ \\
\hline $\ln$ GDP & $\begin{array}{c}-0.0149 \\
(0.0367)\end{array}$ & $\begin{array}{c}0.0577^{*} \\
(0.0301)\end{array}$ & $\begin{array}{c}0.1438 \\
(0.1531)\end{array}$ & $\begin{array}{c}0.6202 \\
(0.7915)\end{array}$ \\
\hline Lag GDP growth & $\begin{array}{c}0.5758^{* * *} \\
(0.0818)\end{array}$ & $\begin{array}{l}0.5016^{* *} \\
(0.1967)\end{array}$ & $\begin{array}{c}0.2277 \\
(0.5437)\end{array}$ & $\begin{array}{c}0.2887 \\
(0.7727)\end{array}$ \\
\hline Share VA & $\begin{array}{c}0.2356^{* * *} \\
(0.0653)\end{array}$ & $\begin{array}{c}0.1729^{* * *} \\
(0.0629)\end{array}$ & $\begin{array}{c}0.0656 \\
(0.9189)\end{array}$ & $\begin{array}{c}0.5202 \\
(0.6963)\end{array}$ \\
\hline Civil Liberties & $\begin{array}{c}0.0138^{* * *} \\
(0.0052)\end{array}$ & $\begin{array}{c}0.0098 \\
(0.0098)\end{array}$ & $\begin{array}{c}-0.0946 \\
(0.0789)\end{array}$ & $\begin{array}{c}-0.4235^{* *} \\
(0.1825)\end{array}$ \\
\hline Human Capital & $\begin{array}{c}0.0256 \\
(0.0190)\end{array}$ & $\begin{array}{c}0.0361 \\
(0.0365)\end{array}$ & $\begin{array}{c}0.2507 \\
(0.2150)\end{array}$ & $\begin{array}{l}-0.4369 \\
(0.5438)\end{array}$ \\
\hline Openness & $\begin{array}{c}0.0023^{* * *} \\
(0.0003)\end{array}$ & $\begin{array}{c}0.0017^{* * *} \\
(0.0005)\end{array}$ & $\begin{array}{c}-0.0004 \\
(0.0014)\end{array}$ & $\begin{array}{c}-0.0002 \\
(0.0037)\end{array}$ \\
\hline Tariff & $\begin{array}{c}-0.0047^{* * *} \\
(0.0012)\end{array}$ & $\begin{array}{l}-0.0006 \\
(0.0023)\end{array}$ & $\begin{array}{c}0.0032 \\
(0.0122)\end{array}$ & $\begin{array}{c}0.1099^{* * *} \\
(0.0324)\end{array}$ \\
\hline MR & & $\begin{array}{c}-0.1068^{* * *} \\
(0.0242)\end{array}$ & $\begin{array}{c}0.0057 \\
(0.0676)\end{array}$ & $\begin{array}{c}0.4895^{* * *} \\
(0.1009)\end{array}$ \\
\hline $\mathrm{MR} \times$ Employ & & $\begin{array}{l}4.1051^{* *} \\
(1.7639)\end{array}$ & $\begin{array}{l}16.1280^{*} \\
(9.5465)\end{array}$ & $\begin{array}{l}16.4613^{*} \\
(9.9455)\end{array}$ \\
\hline British & & $\begin{array}{l}-0.0529^{*} \\
(0.0316)\end{array}$ & & \\
\hline British $\times$ MR & & $\begin{array}{c}0.1492^{* * *} \\
(0.0545)\end{array}$ & & \\
\hline British $\times$ Employ & & $\begin{array}{c}7.1857^{* * *} \\
(2.0053)\end{array}$ & & \\
\hline British $\times$ MR $\times$ Employ & & $\begin{array}{c}1.6225 \\
(2.9783)\end{array}$ & & \\
\hline $\ln$ Area & & $\begin{array}{l}-0.0069 \\
(0.0083)\end{array}$ & $\begin{array}{c}0.0344 \\
(0.0257)\end{array}$ & \\
\hline $\ln$ Pop & & $\begin{array}{l}0.0431^{* *} \\
(0.0174)\end{array}$ & $\begin{array}{l}-0.0657 \\
(0.1057)\end{array}$ & \\
\hline Constant & $\begin{array}{l}1.7093^{* *} \\
(0.7086)\end{array}$ & $\begin{array}{c}-0.7697^{* * *} \\
(0.2466)\end{array}$ & $\begin{array}{c}0.3537 \\
(1.1385)\end{array}$ & $\begin{array}{c}-8.0286 \\
(15.4525)\end{array}$ \\
\hline$N$ & 16293 & 17087 & 2218 & 2218 \\
\hline$R^{2}$ & 0.714 & & & 0.415 \\
\hline log-likelihood & 3003 & 2835 & -2272 & -2222 \\
\hline AIC & -5854 & -5593 & 4581 & 4538 \\
\hline
\end{tabular}

Standard errors clustered in countries (Column $1 \& 4)$ or country-industries $(2 \& 3)$ in parentheses

${ }^{*} p<.1,{ }^{* *} p<.05,{ }^{* * *} p<.01$ 
Fig. 4: Marginal Effects of MR $\times$ British

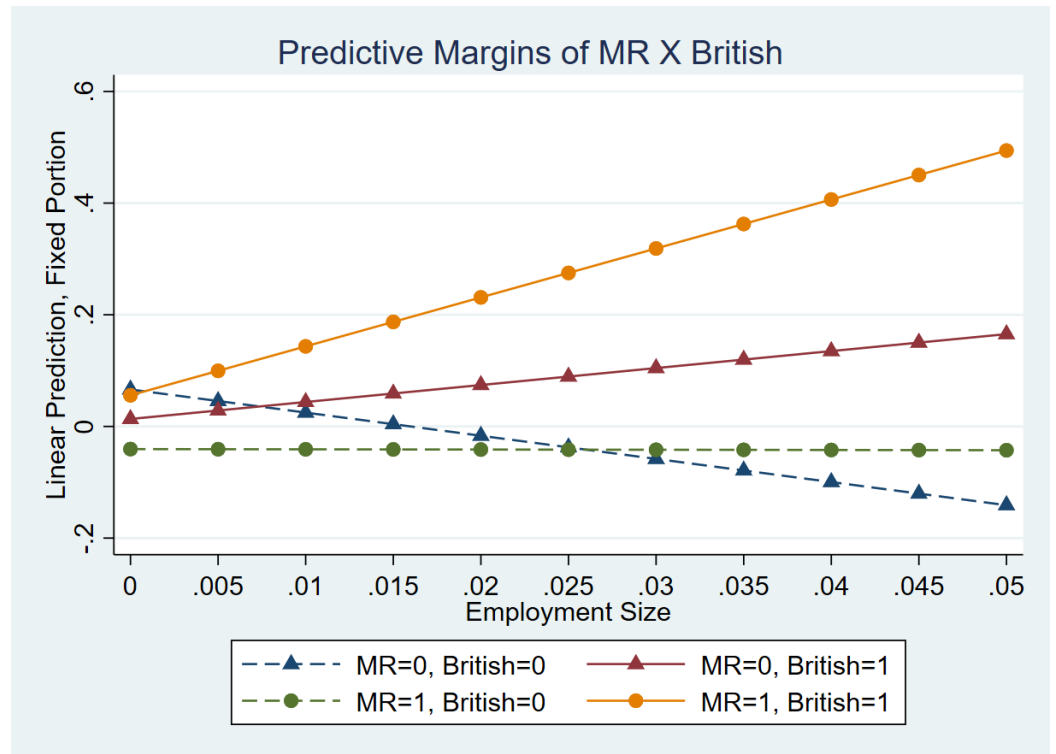

For both British and non-British origins, MR (represented by circles) tends to favour larger industries. Larger employment is even correlated with lower growth rate for non-MR systems of non-British origin countries (represented by triangles and dashed line).

\subsection{Aggregated-level Evidence}

This section proposes two additional robustness checks. Firstly, we collapse the time dimension and attempt to explain average industrial growth by MR and average employment size. To maintain comparability, only those country-industries having at least 10 observations are included in the newly collapsed sample ${ }^{13}$ As the time dimension has been collapsed, we have no longer lags as explanatory variables but the average values. Columns 1 and 2 of Table 5 control for country random effects and fixed effects respectively while pooling observations within countries. We still find positive coefficient of the interaction term between MR and employment size.

The second robustness check is to collapse the country-industry dimension and check if manufacturing employment as a whole and its interaction with MR help explain manufacturing growth. Although our model can also apply to explain manufacturing growth if we, for example, consider manufacturing sector being against agricultural and service sectors. We may be able to conclude that the larger the manufacturing sector the higher the growth under MR, but not under non-MR. Such a finding would also be consistent with our model's prediction. However, we believe that manufacturing sector is perhaps too big a group to target. Moreover, if we find the interaction term is positive and significant, we may suspect the results we obtained in previous sections may simply be a revelation of a overall favourable manufacturing sector policy. Columns 3 and 4 of Table 5 show the random-effect and fixed-effect models that explain total manufacturing growth and find that manufacturing employment is negatively correlated with growth rate, though only significant in the fixed-effect model, and the interaction term shows opposite signs. We can safely exclude the possibility that our main result is actually a revelation of an overall manufacturing-level phenomenon.

\section{Discussion and Conclusion}

Most of the existing studies in constitutional political economy literature have assumed that electoral rules have homogeneous economic consequences within a country. We add to this literature by providing evidence at industry-level, in which we consider that electoral rules might have differential effects across industries operating

\footnotetext{
13 Results still hold with the non-trimmed sample and are not shown in the text, as we stress that a non-trimmed sample produces biased result in a cross-sectional setting.
} 
Table 5: Aggregate-level Evidence

\begin{tabular}{|c|c|c|c|c|}
\hline \multirow[b]{2}{*}{ Aggregated } & $(1)$ & $(2)$ & (3) & (4) \\
\hline & \multicolumn{2}{|c|}{ Country-Industry } & \multicolumn{2}{|c|}{ Country } \\
\hline Country-Industry & Pooled & Pooled & NA & NA \\
\hline Country & RE & $\mathrm{FE}$ & RE & $\mathrm{FE}$ \\
\hline \multirow[t]{2}{*}{ MR } & $-0.0543^{* *}$ & 4.5678 & 0.0713 & $-0.2189^{*}$ \\
\hline & $(0.0224)$ & $(4.2668)$ & $(0.0500)$ & $(0.1273)$ \\
\hline \multirow[t]{2}{*}{ Employ } & $-9.9789^{* * *}$ & $-9.8319^{* * *}$ & & \\
\hline & $(2.5590)$ & $(2.4819)$ & & \\
\hline \multirow[t]{2}{*}{ MR $\times$ Employ } & $5.8856^{* *}$ & $6.0486^{* * *}$ & & \\
\hline & $(2.6928)$ & $(2.2956)$ & & \\
\hline \multirow[t]{2}{*}{ In Manu output } & -0.0215 & -0.0478 & & \\
\hline & $(0.0230)$ & $(0.1077)$ & & \\
\hline \multirow[t]{2}{*}{ Manu growth } & $0.7826^{* * *}$ & $0.7532^{* * *}$ & & \\
\hline & $(0.0842)$ & $(0.0787)$ & & \\
\hline \multirow[t]{2}{*}{$\ln$ GDP } & -0.0053 & 0.6653 & $-0.0339^{* *}$ & $-0.2171^{* * *}$ \\
\hline & $(0.0270)$ & $(0.4089)$ & $(0.0137)$ & $(0.0679)$ \\
\hline \multirow[t]{2}{*}{ GDP growth } & 0.9739 & 3.3972 & & \\
\hline & $(0.9328)$ & $(2.2954)$ & & \\
\hline \multirow[t]{2}{*}{ Share VA } & $0.2059^{*}$ & $0.2425^{* *}$ & 0.5096 & -1.2204 \\
\hline & $(0.1123)$ & $(0.1076)$ & $(0.7404)$ & $(3.0716)$ \\
\hline \multirow[t]{2}{*}{ Civil Liberties } & 0.0275 & -0.0241 & 0.0008 & 0.0034 \\
\hline & $(0.0229)$ & $(0.1390)$ & $(0.0156)$ & $(0.0228)$ \\
\hline \multirow[t]{2}{*}{ Human Capital } & -0.0026 & 0.6641 & 0.0082 & -0.0232 \\
\hline & $(0.0539)$ & $(0.4050)$ & $(0.0499)$ & $(0.0493)$ \\
\hline \multirow[t]{2}{*}{ Trade } & 0.0000 & 0.0033 & $0.0005^{*}$ & $0.0030^{* *}$ \\
\hline & $(0.0004)$ & $(0.0062)$ & $(0.0003)$ & $(0.0011)$ \\
\hline \multirow[t]{2}{*}{ Tariff } & -0.0017 & 0.0326 & $-0.0052^{* * *}$ & $-0.0054^{* *}$ \\
\hline & $(0.0026)$ & $(0.0242)$ & $(0.0017)$ & $(0.0022)$ \\
\hline \multirow[t]{2}{*}{$\ln$ Pop } & $0.0318^{*}$ & & $0.0340^{* *}$ & \\
\hline & $(0.0169)$ & & $(0.0160)$ & \\
\hline \multirow[t]{2}{*}{ ln Area } & 0.0022 & & 0.0073 & \\
\hline & $(0.0057)$ & & $(0.0048)$ & \\
\hline \multirow[t]{2}{*}{ Manu Employ } & & & -0.3705 & $-3.4808^{* * *}$ \\
\hline & & & $(0.2311)$ & $(0.8935)$ \\
\hline \multirow[t]{2}{*}{ MR $\times$ Manu Employ } & & & $-1.5625^{* *}$ & 2.0334 \\
\hline & & & $(0.7363)$ & $(1.7053)$ \\
\hline \multirow[t]{2}{*}{ Lag GDP growth } & & & $0.6150^{* *}$ & $0.5368^{* *}$ \\
\hline & & & $(0.2457)$ & $(0.2252)$ \\
\hline \multirow[t]{2}{*}{ Constant } & -0.0021 & $-15.2541^{*}$ & 0.1097 & $5.6752^{* * *}$ \\
\hline & $(0.1455)$ & $(8.8160)$ & $(0.1986)$ & $(1.7598)$ \\
\hline$N$ & 1888 & 1888 & 393 & 395 \\
\hline log-likelihood & 1230 & 1303 & 319 & 363 \\
\hline Within R-squared & & & 0.9172 & 0.9244 \\
\hline Between R-squared & & & 0.8573 & 0.0664 \\
\hline Overall R-squared & & & 0.9125 & 0.3366 \\
\hline
\end{tabular}

Standard errors clustering in countries (Column 1,3 and 4) and in country-industries (Column 2) in parentheses ${ }^{*} p<.1,{ }^{* *} p<.05,{ }^{* * *} p<.01$

within the same economy. Existing empirical works suggest that more proportional systems favour broad interests, such as education and health programs, whereas plurality systems are more prone to cater to special interest groups. Indeed, trade and industrial policies are often thought to be a politically efficient way to target key voters. Alternative electoral rules are found to interplay with industrial geography to shape electoral incentives and thus, might be conducive to different policy and economic outcomes. Based on these stylized facts, we construct an analytical model to better illustrate the hypothesis that we aim to test against industry-level data. Due to the 
fundamental difference in the rule in determining the allocation of seats, a government under MR is more likely to prioritize larger groups despite the alienating effect on other groups.

We test our hypothesis on data from 61 manufacturing industries operating in 55 countries over 1990-2010. Our results associate majoritarian electoral rules to a growth-diminishing effect in annual growth rates of industries, which however hinges upon the ratio of employees in each industry to total population. Large industries tend not to suffer from the diminishing effect of size under majoritarian rules. This result is robust to a variety of sensitivity checks, such as alternative specifications and estimation techniques. Importantly, our empirical results contribute to a new strand of constitutional political economy literature that advocates for the use of disaggregated data, such as industry-level data of the current paper or firm-level data of Camyar and Ulupinar (2019).

Finally, we would like to strike a note of caution on the external validity of our results. As explained by Rickard (2018), the study of the economic consequences of electoral rules is challenged by causality issues, given the impossibility of controlling for unobservable factors that drive the selection of electoral systems. Keeping this challenge in mind, our goal is to inform new avenues of research, by considering that electoral rules might have heterogeneous implications on the working of different industries within an economy. 


\section{Acknowledges}

We would like to thank the audiences of the 2016 Annual Meeting of the European Public Choice Society in Freiburg (Germany), the 20th Annual Conference of the Society for Institutional \& Organizational Economics in Paris (France) and the 1st Doctoral Conference of the University of the Basque Country in Bilbao (Spain).

Izaskun Zuazu is specially grateful to Joan María Esteban for suggestions on a previous version of the paper, to Shanker Satyanath for discussions on the research and to her Ph.D. advisors Josu Arteche and Annick Laruelle. She acknowledges financial support from the COST Action IC1205 on Computational Social Choice for a short scientific mission at the Toulouse School of Economics (October 2015). This paper has also received financial support from the Spanish Ministry of Science and Innovation and ERDF grant ECO2016-76884-P.

\section{References}

Acemoglu, D., S. Naidu, P. Restrepo, and J. A. Robinson (2015). Democracy, redistribution, and inequality. In Handbook of income distribution, Volume 2, pp. 1885-1966. Elsevier.

Aghion, P., A. F. Alesina, and F. Trebbi (2007). Democracy, technology, and growth.

Alesina, A., S. Özler, N. Roubini, and P. Swagel (1996). Political instability and economic growth. Journal of Economic Growth 1(2), 189-211.

Alfano, M. R. and A. L. Baraldi (2014). Electoral systems and economic growth: What is importance of the proportionality degree? EERI Research Paper Series No 06/2014.

Barro, R. J. and X. Sala-i Martin (1997). Technological diffusion, convergence, and growth. Journal of Economic Growth 2(1), 1-26.

Benhabib, J. and A. Przeworski (2005). Economic growth under political accountability. Manuscript, New York University. Available at: http://politics. as. nyu. edu/docs/IO/2800/account. PDF (accessed 31 August 2010).

Benoit, K. (2004). Models of electoral system change. Electoral studies 23(3), 363-389.

Blais, A., E. Guntermann, and M. A. Bodet (2017). Linking party preferences and the composition of government: A new standard for evaluating the performance of electoral democracy. Political Science Research and Methods 5(2), 315-331.

Blais, A. and L. Massicotte (1997). Electoral formulas: a macroscopic perspective. European Journal of Political Research 32(1), 107-129.

Boix, C. (1999). Setting the rules of the game: the choice of electoral systems in advanced democracies. American Political Science Review 93(03), 609-624.

Bormann, N.-C. and M. Golder (2013). Democratic electoral systems around the world, 1946-2011. Electoral Studies 32(2), 360-369.

Camyar, I. and B. Ulupinar (2019). Electoral systems and the economy: a firm-level analysis. Constitutional Political Economy 30(1), 1-30.

Carey, J. and S. Hix (2011). The electoral sweet spot: Low-magnitude proportional electoral systems. American Journal of Political Science 55(2), 383-397.

Carey, J. and S. Hix (2013). Policy consequences of electoral rules. Political Science, Electoral Rules, and Democratic Governance, 46-55.

Chang, E. C. (2008). Electoral incentives and budgetary spending: rethinking the role of political institutions. The Journal of Politics 70(4), 1086-1097.

Colagrossi, M., D. Rossignoli, and M. A. Maggioni (2020). Does democracy cause growth? a meta-analysis (of 2000 regressions). European Journal of Political Economy 61, 101824.

Colomer, J. (2016). The handbook of electoral system choice. Springer.

De Haan, J. and J. Klomp (2013). Conditional political budget cycles: a review of recent evidence. Public Choice 157(3-4), 387-410. 
Dimico, A. (2017). Size matters: the effect of the size of ethnic groups on development. Oxford Bulletin of Economics and Statistics 79(3), 291-318.

Doucouliagos, H. and M. A. Ulubaşoğlu (2008). Democracy and economic growth: a meta-analysis. American Journal of Political Science 52(1), 61-83.

Esteban, J. and D. Ray (2001). Collective action and the group size paradox. American Political Science Review 95(3).

Fiva, J. H. and O. Folke (2016). Mechanical and psychological effects of electoral reform. British Journal of Political Science 46(2), 265-279.

Gallagher, M. (1991). Proportionality, disproportionality and electoral systems. Electoral Studies 10(1), 33-51.

Glaeser, E. L., R. La Porta, F. Lopez-de Silanes, and A. Shleifer (2004). Do institutions cause growth? Journal of Economic Growth 9(3), 271-303.

Golder, M. (2005). Democratic electoral systems around the world, 1946-2000. Electoral Studies 24(1), 103-121. Grier, K. (2008). Us presidential elections and real gdp growth, 1961-2004. Public Choice 135(3-4), 337-352.

Grossman, G. M. and E. Helpman (2001). Special interest politics. MIT press.

Knutsen, C. H. (2011). Which democracies prosper? electoral rules, form of government and economic growth. Electoral Studies 30(1), 83-90.

Krūminas, P. (2019). Public r\&d under different electoral rules: evidence from oecd countries. Constitutional Political Economy, 1-30.

Leonida, L., D. M. A. Patti, and P. Navarra (2013). Testing the political replacement effect: a panel data analysis. Oxford Bulletin of Economics and Statistics 75(6), 785-805.

Lijphart, A. (1990). The political consequences of electoral laws, 1945-85. American Political Science Review 84(2), 481-496.

Lijphart, A. (2012). Patterns of democracy: Government forms and performance in thirty-six countries. Yale University Press.

Lizzeri, A. and N. Persico (2001). The provision of public goods under alternative electoral incentives. American Economic Review, 225-239.

Lucas, R. E. (1988). On the mechanics of economic development. Journal of Monetary Economics 22(1), 3-42.

Martin, C. W. and N. D. Steiner (2016). Economic globalization and the change of electoral rules. Constitutional Political Economy 27(4), 355-376.

McGillivray, F. (2018). Privileging industry: The comparative politics of trade and industrial policy. Princeton University Press.

Milesi-Ferretti, G. M., R. Perotti, and M. Rostagno (2002). Electoral systems and public spending. Quarterly Journal of Economics 117(2), 609-657.

Norris, P. (2004). Electoral engineering: Voting rules and political behavior. Cambridge University Press.

Persson, T., G. Roland, and G. Tabellini (2003). How do electoral rules shape party structures, government coalitions, and economic policies? Technical report, National Bureau of Economic Research.

Persson, T. and G. Tabellini (1999). The size and scope of government: Comparative politics with rational politicians. European Economic Review 43(4), 699-735.

Persson, T. and G. Tabellini (2004). Constitutional rules and fiscal policy outcomes. American Economic Review 94(1), 25-45.

Persson, T. and G. Tabellini (2006). Democracy and development: The devil in the details. American Economic Review 96(2), 319-324.

Persson, T. and G. E. Tabellini (2005). The Economic Effects of Constitution. MIT Press.

Pesaran, M. H. and Q. Zhou (2018). Estimation of time-invariant effects in static panel data models. Econometric Reviews 37(10), 1137-1171.

Pierzgalski, M. (2018). Balancing disproportionality and parliament fragmentation: A simulation study of the mechanical effects of district magnitude on electoral outcomes. Electoral Studies 54, 205-217. 
Powell, G. B. (2000). Elections as instruments of democracy: Majoritarian and proportional visions.

Powell Jr, G. B. and G. D. Whitten (1993). A cross-national analysis of economic voting: taking account of the political context. American Journal of Political Science, 391-414.

Przeworski, A. (2000). Democracy and development: political institutions and well-being in the world, 1950-1990, Volume 3. Cambridge University Press.

Rickard, S. J. (2012a). Electoral systems, voters' interests and geographic dispersion. British Journal of Political Science 42(4), 855-877.

Rickard, S. J. (2012b). Welfare versus subsidies: Governmental spending decisions in an era of globalization. Journal of Politics 74(04), 1171-1183.

Rickard, S. J. (2018). Economic Geography, Electoral Institutions, and the Politics of Redistribution: Political Institutions, Economic Geography, and Government Subsidies. Cambridge University Press.

Rodrik, D. (1996). Understanding economic policy reform. Journal of Economic Literature 34(1), 9-41.

Rodrik, D. (2012). Unconditional convergence in manufacturing. Quarterly Journal of Economics 128(1), 165204.

Rogowski, R. (1987). Trade and the variety of democratic institutions. International Organization 41(02), 203223.

Rokkan, S. (1970). Citizens, Elections, Parties: Approaches to the Comparative Study of the Process of Development. Oslo: Universiteesforlaget.

Stockemer, D. and A. Sundström (2016). Modernization theory: How to measure and operationalize it when gauging variation in women's representation? Social Indicators Research 125(2), 695-712.

Taagepera, R. (1997). Effective number of parties for incomplete data. Electoral Studies 16(2), 145-151.

Taagepera, R. and M. Qvortrup (2012). Who gets what, when, how-through which electoral system? European Political Science 11(2), 244-258.

Voigt, S. (2011). Positive constitutional economics ii-a survey of recent developments. Public Choice 146(1-2), 205-256.

Yeung, T. Y.-C. (2017). Political philosophy, executive constraint and electoral rules. Journal of Comparative Economics 45(1), 67-88.

Zuazu, I. (2019). The growth effect of democracy and technology: An industry disaggregated approach. European Journal of Political Economy 56, 115-131. 


\section{Appendix}

Data in Brief

Table A.1: Sample Countries by Electoral System

\begin{tabular}{|c|c|c|c|}
\hline \multirow{2}{*}{$\begin{array}{l}\text { MR } \\
\text { Australia }\end{array}$} & \multicolumn{2}{|c|}{$\overline{P R}$} & \multirow{2}{*}{$\begin{array}{l}\text { MS } \\
\text { Bolivia (PR to MS, 1997) }\end{array}$} \\
\hline & Albania (MS to PR, 2009) & Kyrgyzstan & \\
\hline Canada & Argentina & Latvia & Bulgaria (PR to MS, 2009) \\
\hline France & Austria & Luxembourg & Ecuador (PR to MS, 1998) \\
\hline India & Belgium & Malta & Georgia \\
\hline Malawi & Brazil & Moldova & Germany \\
\hline Mauritius & Sri Lanka & Netherlands & Greece (PR to MS,2007) \\
\hline Mongolia & Chile & Norway & Italy (PR to MS,1994) \\
\hline Trinidad and Tobago & Colombia & Paraguay & Japan (MR to MS, 1996) \\
\hline United Kingdom & Cyprus & Peru & South Korea \\
\hline \multirow[t]{7}{*}{ United States of America } & Czech Republic & Portugal & Lithuania \\
\hline & Denmark & Slovakia & Madagascar \\
\hline & Estonia & Slovenia & Mexico \\
\hline & Finland & Spain & Panama \\
\hline & Indonesia & Sweden & Philippines (MR to MS,1998) \\
\hline & Ireland & Macedonia (MR to PR,1998) & Romania (PR to MS,2008) \\
\hline & Israel & Uruguay & Senegal \\
\hline
\end{tabular}

Table A.2: Industries in the Sample

151 Processed meat,fish,fruit,vegetables,fats 1520 Dairy products

153 Grain mill products; starches; animal feeds 154 Other food products

155 Beverages

1600 Tobacco products

171 Spinning, weaving and finishing of textiles

172 Other textiles

1730 Knitted and crocheted fabrics and articles

1810 Wearing apparel, except fur apparel

1820 Dressing \& dyeing of fur; processing of fur

191 Tanning, dressing and processing of leather

920 Footwear

2010 Sawmilling and planing of wood

202 Products of wood, cork, straw, etc.

210 Paper and paper products

221 Publishing

222 Printing and related service activities

2230 Reproduction of recorded media

2310 Coke oven products

2320 Refined petroleum products

2330 Processing of nuclear fuel

241 Basic chemicals

242 Other chemicals

2430 Man-made fibres

251 Rubber products

2520 Plastic products

2610 Glass and glass products

269 Non-metallic mineral products n.e.c.

2710 Basic iron and steel

2720 Basic precious and non-ferrous metals
273 Casting of metals

281 Struct.metal products;tanks;steam generators

289 Other metal products; metal working services

291 General purpose machinery

292 Special purpose machinery

2930 Domestic appliances n.e.c.

3000 Office, accounting and computing machinery

3110 Electric motors, generators and transformers

3120 Electricity distribution \& control apparatus

3130 Insulated wire and cable

3140 Accumulators, primary cells and batteries

3150 Lighting equipment and electric lamps

3190 Other electrical equipment n.e.c.

3210 Electronic valves, tubes, etc.

$3220 \mathrm{TV} /$ radio transmitters; line comm. apparatus

$3230 \mathrm{TV}$ and radio receivers and associated goods

331 Medical, measuring, testing appliances, etc.

3320 Optical instruments \& photographic equipment

3330 Watches and clocks

3410 Motor vehicles

3420 Automobile bodies, trailers \& semi-trailers

3430 Parts/accessories for automobiles

351 Building and repairing of ships and boats

3520 Railway/tramway locomotives \& rolling stock

3530 Aircraft and spacecraft

359 Transport equipment n.e.c.

3610 Furniture

369 Manufacturing n.e.c.

3710 Recycling of metal waste and scrap

3720 Recycling of non-metal waste and scrap

61 ISIC industries from INDSTAT from UNIDO (3 digit-level 2010, rev. 3) 
Table A.3: Data Sources

\begin{tabular}{|c|c|c|c|}
\hline Variable & "Description & 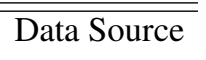 & \\
\hline Growth & Annual growth rates at manufacturing industry-level & UNIDO & \\
\hline Manu. Employ & Employment in manufacturing sector to total population ratio & $\begin{array}{l}\text { UNIDO \& } \\
\text { Bank }\end{array}$ & World \\
\hline Industry Employ & Industry employment to total population ratio. & $\begin{array}{l}\text { UNIDO \& } \\
\text { Bank }\end{array}$ & World \\
\hline Industry Output Share & Industry output to manufacturing sector output ratio. & UNIDO & \\
\hline In Industry Output & Natural logarithm of industry output. & UNIDO & \\
\hline Manu & Natural logarithm of manufacturing sector output. & UNIDO & \\
\hline Manu Growth & Annual growth rates of manufacturing sector output. & UNIDO & \\
\hline MR & $\begin{array}{l}\text { Dichotomous variable that takes on the value } 1 \text { when a country } \\
\text { is a majoritarian system, } 0 \text { otherwise. }\end{array}$ & $\begin{array}{l}\text { Bormann and } \\
\text { (2013) }\end{array}$ & Golder \\
\hline PR & $\begin{array}{l}\text { Dichotomous variable that takes on the value } 1 \text { when a country } \\
\text { is a proportional representation system, } 0 \text { otherwise. }\end{array}$ & $\begin{array}{l}\text { Bormann and } \\
\text { (2013) }\end{array}$ & Golder \\
\hline Mixed & $\begin{array}{l}\text { Dichotomous variable that takes on the value } 1 \text { when a country } \\
\text { is a mixed system, } 0 \text { otherwise. }\end{array}$ & $\begin{array}{l}\text { Bormann and } \\
\text { (2013) }\end{array}$ & Golder \\
\hline GDP per capita & $\begin{array}{l}\text { Natural logarithm of gross domestic product divided by midyear } \\
\text { population in current U.S. dollars. }\end{array}$ & World Bank & \\
\hline GDPpc Growth & Annual growth rate of GDP Per Capita. & World Bank & \\
\hline Human Capital & $\begin{array}{l}\text { Total enrollment in secondary education as a percentage of the } \\
\text { population of official secondary education age. }\end{array}$ & $\begin{array}{l}\text { UNESCO, } \\
\text { Bank }\end{array}$ & World \\
\hline Civil Liberties (CL) & $\begin{array}{l}\text { Survey indicator based on freedom of expression and belief, } \\
\text { associational and organizational rights, rule of law, and personal } \\
\text { and individual rights, rescaled and ranging from } 1 \text { (lowest) to } 7 \\
\text { (highest level of CL). }\end{array}$ & Freedom Hou & \\
\hline In Population & Natural logarithm of total population. & $\begin{array}{l}\text { World Bank } \\
\text { April 2014) }\end{array}$ & (ver. \\
\hline Openness (Trade Ratio) & $\begin{array}{l}\text { The sum of exports and imports of goods and services measured } \\
\text { as a share of gross domestic product. }\end{array}$ & World Bank & \\
\hline Tariff on Manufacturing & $\begin{array}{l}\text { Simple mean applied tariff is the unweighted average of } \\
\text { effectively applied rates for manufacturing products subject to } \\
\text { tariffs calculated for traded goods }\end{array}$ & World Bank & \\
\hline GI index & $\begin{array}{l}\text { Gallagher Index compares vote share to seat share of parties in } \\
\text { parliaments, a score of } 0 \text { would indicated a perfect proportional } \\
\text { vote-seat relation. }\end{array}$ & $\begin{array}{l}\text { Christopher C } \\
\text { database }\end{array}$ & Srandud \\
\hline ENEP & $\begin{array}{l}\text { Effective number of electoral parties as defined by Taagepera } \\
\text { (1997) }\end{array}$ & $\begin{array}{l}\text { Bormann and } \\
(2013)\end{array}$ & Golder \\
\hline
\end{tabular}


Table A.4: Within-Country Information

\begin{tabular}{|c|c|c|c|c|c|}
\hline Country & Industry growth rate & 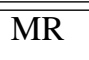 & Industry Employment & "Gallagher index & 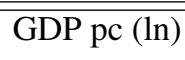 \\
\hline Albania & $7.5 \%$ & 0.00 & $0.09 \%$ & 16.93 & 22.92 \\
\hline Argentina & $-5.2 \%$ & 0.00 & $0.04 \%$ & 7.52 & 26.40 \\
\hline Australia & $-5.7 \%$ & 1.00 & $0.11 \%$ & 10.58 & 27.59 \\
\hline Austria & $4.7 \%$ & 0.00 & $0.15 \%$ & 2.07 & 26.50 \\
\hline Belgium & $6.9 \%$ & 0.00 & $0.10 \%$ & 3.81 & 26.74 \\
\hline Bolivia & $3.5 \%$ & 0.00 & $0.01 \%$ & 3.72 & 23.25 \\
\hline Brazil & $5.8 \%$ & 0.00 & $0.06 \%$ & 4.20 & 28.13 \\
\hline Bulgaria & $7.2 \%$ & 0.00 & $0.15 \%$ & 5.51 & 24.34 \\
\hline Canada & $4.7 \%$ & 1.00 & $0.10 \%$ & 13.62 & 27.89 \\
\hline Sri Lanka & $-29.5 \%$ & 0.00 & $0.10 \%$ & & 24.63 \\
\hline Chile & $35.3 \%$ & 0.00 & $0.05 \%$ & 6.79 & 25.96 \\
\hline Colombia & $8.4 \%$ & 0.00 & $0.02 \%$ & 3.98 & 26.14 \\
\hline Cyprus & $2.4 \%$ & 0.00 & $0.08 \%$ & 1.87 & 23.79 \\
\hline Czech Republic & $12.9 \%$ & 0.00 & $0.23 \%$ & 6.27 & 25.79 \\
\hline Denmark & $2.4 \%$ & 0.00 & $0.17 \%$ & 1.16 & 26.41 \\
\hline Ecuador & $7.6 \%$ & 0.00 & $0.02 \%$ & 4.96 & 24.64 \\
\hline Estonia & $11.2 \%$ & 0.00 & $0.22 \%$ & 3.51 & 23.62 \\
\hline Finland & $2.2 \%$ & 0.00 & $0.17 \%$ & 3.39 & 26.02 \\
\hline France & $1.9 \%$ & 1.00 & $0.10 \%$ & 20.13 & 28.48 \\
\hline Georgia & $4.5 \%$ & 0.00 & $0.04 \%$ & & 23.02 \\
\hline Germany & $3.1 \%$ & 0.00 & $0.15 \%$ & 3.87 & 28.79 \\
\hline Greece & $15.1 \%$ & 0.00 & $0.05 \%$ & 8.79 & 26.24 \\
\hline India & $8.6 \%$ & 1.00 & $0.01 \%$ & 7.43 & 27.57 \\
\hline Indonesia & $4.4 \%$ & 0.00 & $0.04 \%$ & 3.97 & 27.00 \\
\hline Ireland & $7.4 \%$ & 0.00 & $0.12 \%$ & 5.32 & 25.68 \\
\hline Israel & $3.3 \%$ & 0.00 & $0.13 \%$ & 2.20 & 25.84 \\
\hline Italy & $7.4 \%$ & 0.00 & $0.11 \%$ & 7.20 & 28.32 \\
\hline
\end{tabular}


Table A.4: Within-Country Information (cont.)

\begin{tabular}{|c|c|c|c|c|c|}
\hline Country & Industry growth rate & MR & Industry Employment & Gallagher index & $\overline{\mathrm{GDP}} \mathrm{pc}(\ln )$ \\
\hline Japan & $-2.8 \%$ & 0.14 & $0.12 \%$ & 11.98 & 29.31 \\
\hline South Korea & $11.7 \%$ & 0.00 & $0.20 \%$ & 11.64 & 27.21 \\
\hline Kyrgyzstan & $-36.7 \%$ & 0.00 & $0.02 \%$ & & 22.28 \\
\hline Latvia & $9.6 \%$ & 0.00 & $0.15 \%$ & 5.48 & 23.62 \\
\hline Lithuania & $8.1 \%$ & 0.00 & $0.13 \%$ & 8.77 & 24.20 \\
\hline Madagascar & $-13.9 \%$ & 0.00 & $0.16 \%$ & & 22.86 \\
\hline Malawi & $11.5 \%$ & 1.00 & $0.02 \%$ & & 22.29 \\
\hline Mauritius & $-6.9 \%$ & 1.00 & $0.50 \%$ & 28.64 & 22.71 \\
\hline Mexico & $-26.4 \%$ & 0.00 & $0.04 \%$ & 7.78 & 27.66 \\
\hline Mongolia & $-4.2 \%$ & 1.00 & $0.06 \%$ & 24.30 & 22.08 \\
\hline Moldova & $6.0 \%$ & 0.00 & $0.09 \%$ & 12.47 & 22.26 \\
\hline Netherlands & $6.6 \%$ & 0.00 & $0.09 \%$ & 1.13 & 27.29 \\
\hline Norway & $12.7 \%$ & 0.00 & $0.12 \%$ & 3.39 & 26.59 \\
\hline Paraguay & $-27.8 \%$ & 0.00 & $0.03 \%$ & & 23.23 \\
\hline Peru & $0.0 \%$ & 0.00 & $0.10 \%$ & 8.87 & 25.22 \\
\hline Philippines & $-1.7 \%$ & 0.51 & $0.04 \%$ & 25.16 & 25.54 \\
\hline Portugal & $5.3 \%$ & 0.00 & $0.16 \%$ & 5.00 & 26.12 \\
\hline Romania & $6.6 \%$ & 0.00 & $0.32 \%$ & 5.06 & 25.59 \\
\hline Senegal & $-10.4 \%$ & 0.00 & $0.01 \%$ & 19.28 & 22.93 \\
\hline Slovakia & $9.5 \%$ & 0.00 & $0.15 \%$ & 5.31 & 24.81 \\
\hline Slovenia & $-0.6 \%$ & 0.00 & $0.22 \%$ & 3.18 & 24.37 \\
\hline Spain & $8.2 \%$ & 0.00 & $0.09 \%$ & 5.63 & 27.76 \\
\hline Sweden & $5.5 \%$ & 0.00 & $0.14 \%$ & 1.73 & 26.66 \\
\hline Trinidad and Tobago & $-5.4 \%$ & 1.00 & $0.08 \%$ & 2.88 & 23.21 \\
\hline Macedonia & $-2.6 \%$ & 0.04 & $0.16 \%$ & 8.33 & 22.78 \\
\hline United Kingdom & $7.2 \%$ & 1.00 & $0.11 \%$ & 17.07 & 28.34 \\
\hline United States of America & $3.7 \%$ & 1.00 & $0.10 \%$ & 2.75 & 30.19 \\
\hline Uruguay & $-6.1 \%$ & 0.00 & $0.04 \%$ & 0.71 & 24.09 \\
\hline
\end{tabular}

